\title{
A remarkable Amgan (Middle Cambrian, Stage 5) fauna from the Sauk Tanga, Madygen region, Kyrgyzstan
}

\author{
Gerd Geyer, John S. Peel, Michael Streng, Sebastian Voigt, Jan Fischer \& \\ MARVIN PREUBE
}



\begin{abstract}
Early Middle Cambrian bituminous coquinoid limestones from a tectonically isolated outcrop in southwestern Kyrgyzstan yield a remarkably diverse fauna, with stem-group cnidarians, trilobites, rhynchonelliformean brachiopods, and other shelly fossils. The fossil site is in the northern foothills of the Turkestan Range and thus forms part of the westernmost extension of the South Tien Shan. The fauna includes two fairly well known trilobite species, Glabrella ventrosa Lermontova, 1940 and Dorypyge richthofeniformis Lermontova, 1940, that provide confident support for an Amgan age of the rocks. New described taxa include the stem-group cnidarian Cambroctoconus kyrgyzstanicus Peel sp. nov., the trilobite Olenoides sagittatus Geyer sp. nov., and the helcionelloid Manasoconus bifrons Peel gen. et sp. nov. Additional fossils within the samples include the trilobites Olenoides sp. A, Kootenia sp., and Pseudoeteraspis? sp.; the rhynchonelliform brachiopods Narynella cf. ferganensis (Andreeva, 1962), Narynella? sp., Austrohedra? sp. nov., and two species of uncertain generic affinity; the tommotiid Tesella sp.; the hyolithelminth Hyolithellus sp.; and the palaeoscolecid Hadimopanella oezgueli Gedik, 1977. Of particular interest is Cambroctoconus kyrgyzstanicus with an octagonal corallum and a sparsely septate calyx. - Key words: Middle Cambrian, Cnidaria, Mollusca, Trilobita, Brachiopoda, Tommotiida, Palaeoscolecida, Kyrgyzstan.
\end{abstract}

Geyer, G., Peel, J.S., Streng, M., Voigt, S., Fischer, J. \& Preuße, M. 2014. A remarkable Amgan (Middle Cambrian, Stage 5) fauna from the Sauk Tanga, Madygen region, Kyrgyzstan. Bulletin of Geosciences 89(2), 375-400 (10 figures). Czech Geological Survey, Prague. ISSN 1214-1119. Manuscript received March 23, 2013; accepted in revised form March 21, 2014; published online May 2, 2014; issued May 19, 2014.

Gerd Geyer, Institut für Geographie und Geologie, Lehrstuhl für Geodynamik und Geomaterialforschung, Bayerische Julius-Maximilians-Universität Würzburg, Am Hubland, D-97074 Würzburg, Germany, and Department of Earth Sciences (Palaeobiology), Uppsala University, Villavägen 16, SE-752 36 Uppsala, Sweden; gerd.geyer@uni-wuerzburg.de - John S. Peel \& Michael Streng, Department of Earth Sciences (Palaeobiology), Uppsala University, Villavägen 16,SE-752 36 Uppsala, Sweden; john.peel@pal.uu.se, michael.streng@geo.uu.se - Sebastian Voigt \& Jan Fischer, Urweltmuseum GEOSKOP, Burg Lichtenberg (Pfalz), D-66871 Thallichtenberg, Germany; s.voigt@pfalzmuseum.bv-pfalz.de,j.fischer1@yahoo.de•Marvin Preuße,Universität Köln, Institut für Geologie und Mineralogie, Zülpicher Straße 49a-b, D-50674 Köln, Germany; mpreusse@uni-koeln.de

Cambrian rocks from western Kyrgyzstan are known only from rare, scattered occurrences and usually only the trilobite and brachiopod faunas are described. Here, we present preliminary data on a tectonically isolated occurrence of tremendously fossiliferous lower Middle Cambrian bioclastic limestone with a surprisingly complex macrofossil assemblage.

The material was collected between 2007 and 2009 during geological mapping in the stratotype area of the Triassic Madygen Formation. Large-scale geological mapping in this area is part of a research project, which focuses on the palaeoenvironmental reconstruction of the renowned Madygen Lagerstätte (e.g., Voigt et al. 2006, Shcherbakov 2008, Berner et al. 2009, Voigt et al. 2009, Schoch et al. 2010, Voigt \& Hoppe 2010, Fischer et al. 2011, Moisan et al. 2011).

\section{Geological setting}

All fossils described herein come from a single locality in the Sauk Tanga (or "Sauk Tan'ga"; FG locality 596/III/11; $\left.40^{\circ} 01^{\prime} 33.4^{\prime \prime} \mathrm{N}, 70^{\circ} 16^{\prime} 18.3^{\prime \prime} \mathrm{E}\right)$ about $50 \mathrm{~km}$ to the west of Batken, the capital of the eponymous district in southwestern Kyrgyzstan, Central Asia (Fig. 1A). The fossil site is situated in the northern foothills of the Turkestan Range and thus part of the westernmost extension of the South Tien Shan. The local name Sauk Tan'ga means "cool ravine" and refers to a deep, dry valley ca $2 \mathrm{~km}$ east of Madygen village (Dobruskina 1995; Voigt et al. 2006). A fossil sample locality in the Sauk Tanga canyon area, which produced Amgan fossils, is listed in Repina et al. (1975, p. 103) under their locality " 27 ". This locality is possibly 


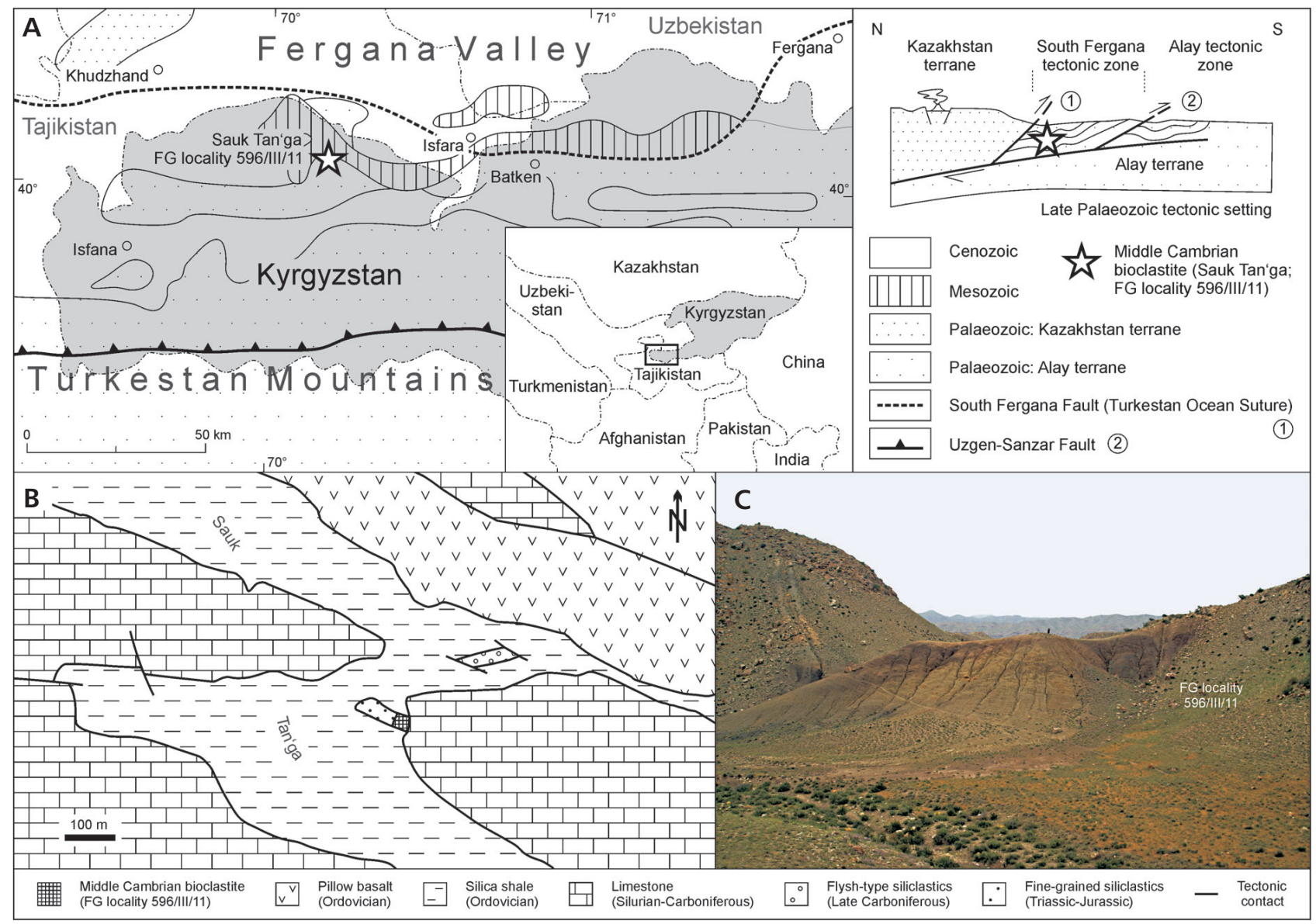

Figure 1. Location and geological overview of the study area. - A - position of Sauk Tanga in southwest Kyrgyzstan and schematic expression of the Late Palaeozoic tectonic setting of the region. • B - geological sketch map of the southern part of the Sauk Tanga valley (modified from Preuße 2011). - $\mathrm{C}$ - fossil site seen from south; persons in the centre for scale.

identical with the locality from which the herein described material originated although a symbol in the sketch map points to a slightly different location. However, the information provided by Repina et al. (1975) is insufficient for a precise location.

The outcrop area of the Cambrian rocks is an approximately $20 \times 30 \mathrm{~m}$ large natural exposure of dark brown to greyish-black bituminous limestone on the right bank of the southern part of the Sauk Tanga valley (Fig. 1B, C). The richly fossiliferous, coquinoid rock lacks bedding and breaks down into irregular fragments with uneven surfaces. Tectonic fracturing promotes deep weathering of the limestone so that fallen rock covers most of the slope below the outcrop.

This small occurrence of bituminous limestone is fault-bounded in all directions, juxtaposed against heavily tectonised Ordovician silica shale in the north and south, Silurian-Carboniferous marine limestone in the east, and Triassic-Jurassic continental deposits in the west (Fig. 1C; Berezanskii 1999, Preuße 2011). On account of its detached nature and the biostratigraphically inferred
Middle Cambrian age, which is in contrast to the surrounding rocks, we interpret the fossil-bearing bituminous limestone at this locality as a tectonically emplaced fragment.

The Palaeozoic evolution of the relevant part of Central Asia that includes the study area is mainly the history of the Turkestan Ocean (Burtman 1997, 2008). Throughout the early and mid Palaeozoic, the region has been a shallow to deep marine depositional environment. In the Early Carboniferous, the closure of the Turkestan Ocean started by subduction of oceanic crust beneath the present-day northern Kazakh-Kyrgyz terrane. Crustal shortening culminated in a continent-continent collision with the Alay terrane at the end of this period. The Palaeozoic Turkestan Ocean suture is reflected by the roughly E-W directed South Fergana Fault running a few kilometres to the north of the study area (Fig. 1A). It is suggested that the bituminous limestone of FG locality 596/III/11 originated at an unknown place in the Turkestan Ocean, was transported to the north during the closure of the Turkestan Ocean, and finally became part of the accretionary wedge that formed 
in front of the Kazakh-Kyrgyz continent. The present-day position of the Cambrian limestone adjacent to faultbounded Mesozoic rocks is a result of Cenozoic deformation related to the modern Tien Shan uplift (Bazhenov 1993, Yin 2010).

\section{Age and stratigraphic position}

The age of the fossiliferous rock from the Sauk Tanga locality can be deduced with some confidence from the two well-known species of trilobites, which occur in the sample. Glabrella ventrosa Lermontova, 1940 and Dorypyge richthofeniformis Lermontova, 1940 are both species exclusively known from the Middle Cambrian Amgan Stage and probably from only the upper part termed the Sdzuyella-Aegunaspis Zone in the Turkestan and Alay ranges (see Repina et al. 1975). The only exception is a report of immature silicified material of Dorypyge richthofeniformis from the eastern Alay Range from the younger Pseudanomocarina Zone (Ghobadi Pour \& Popov 2009), but this determination remains problematic as long as adult specimens are not known from these beds. Other trilobites as well as the brachiopods in the Sauk Tanga samples do not provide a precise age, but are frequently found in strata of upper Amgan age.

\section{Facial and depositional characteristics}

The rocks are generally dark brownish to greyish-black bituminous limestones developed as abundantly fossiliferous coquinas without well recognizable bedding. They break down into irregular fragments with uneven surfaces that, when fresh, emit a slightly sulphuric smell originating from processed organic matter. The primary calcareous matrix is totally recrystallised to sparitic calcite with often large epipedic crystals. Two types of fossil fragments can be distinguished, one being smaller particles of shelly fossils with slightly to well-rounded edges of the fractured faces and thus transported over a considerable distance or reworked; the other consisting of shell or sclerite fragments with sharp edges and thus more or less deposited in situ. The presence of these two types of fossil remains with obvious different depositional histories is in accordance with the poorly visible stratification of the rocks, the absence of a preferred orientation of shell fragments and sclerites, and the assemblage of species from systematic groups with different ecologic preferences, such as trilobites and helcionelloids as vagile benthic organisms including probable scavengers, and articulate brachiopods and cnidarians as sessile filter feeders with different types of attachment to the substrate.

\section{Systematic palaeontology}

The material is deposited in the geological collections of the Technische Universität Bergakademie Freiberg, Germany, under the cumulative collection number FG 596/XII. The additional terminal number refers to individual rock samples (001 through 033 ) or an electron microscope stub (034), the individual specimens on which are identified by a to [n]; e.g. specimen FG 596/XII/010c is derived from rock sample 10 of the collection.

\section{Stem-group Cnidaria}

Genus Cambroctoconus Park, Woo, Lee, Lee, Lee, Han, Chough \& Choi, 2011

Type species (by original designation). - Cambroctoconus orientalis Park, Woo, Lee, Lee, Lee, Han, Chough \& Choi, 2011. Middle Cambrian (Cambrian Series 3, Drumian Stage), Changhia Formation, Shandong Province, China.

Discussion. - Park et al. (2011) focused on the octagonal cross-section of the corallum, the perforated wall and the presence of paired internal septa originating from each of the corners of the calyx when proposing Cambroctoconus as a stem-group cnidarian. A similar octagonal crosssection and much shorter, stubby, septa are seen in Tretocylichne Engelbretsen (1993) from the Murrawong Creek Formation of New South Wales (Middle Cambrian; Series 3 , Stage 5) but the base in the Australian form has a broad basal holdfast-like structure which is perforated centrally (Engelbretsen 1993), unlike the closed tip of Cambroctoconus; pores are not reported in Tretocylichne. Cothonion Jell \& Jell, 1976, from the latest early Cambrian (Series 2, Stage 4) of Australia and Greenland, lacks the octagonal form and the pores characteristic of Cambroctoconus whilst the conical corallum carries numerous internal short septa or septal grooves (Jell \& Jell 1976, Peel 2011).

\section{Cambroctoconus kyrgyzstanicus Peel sp. nov.}

Figure 2

Holotype. - FG 596/XII/034a (Fig. 2E, G, I).

Type locality and horizon. - Sauk Tanga, FG locality $596 / \mathrm{III} / 11,40^{\circ} 01^{\prime} 33.4^{\prime \prime} \mathrm{N}, 70^{\circ} 16^{\prime} 18.3^{\prime \prime} \mathrm{E}$; Alay range, western Kyrgyzstan, upper Amgan Stage.

Paratypes. - FG 596/XII/001c, FG 596/XII/001e, FG 596/XII/001f, FG 596/XII/001g, FG 596/XII/007d, FG 596/XII/007e, FG 596/XII/007f, FG 596/XII/017a, FG 596/XII/019a, FG 596/XII/020c, FG 596/XII/020d, 
FG 596/XII/020e, FG 596/XII/021a, FG 596/XII/022a, FG 596/XII/034a.

Etymology. - From Kyrgyzstan, the Kyrgyz Republic.

Diagnosis. - Corallum trochoidal, octagonal in crosssection, with broad longitudinal angulations separated by flat to shallowly concave fields. Calyx deep, without septa or with only isolated septa or short, broad, septal spines, possibly with a basal transverse tabula or apical plug; theca porous, with densely packed, meandering pores.

Description. - The maximum known length of the slightly curved corallum is about $7 \mathrm{~mm}$, with observed width varying between 5 and $8 \mathrm{~mm}$; the tip is blunt. In cross-section the corallum is octagonal, usually with broad, rounded longitudinal angulations separated by shallowly concave longitudinal fields (Fig. 2C-E). The calyx varies from equidimensional (Fig. 2A, C, F) to wider in the plane transverse to the plane of curvature (Fig. 2E, I). The thecal walls are perforated by a tight meshwork of meandering pores composing about one third of the surface area (Fig. 2G, K). The calyx is deep, without observed tabulae, but crystalline spar in some specimens as preserved suggests apical fill or the presence of a tabula. Internally, the calyx preserves infrequent, short, stubby septa or septal spines (Fig. 2F), although one specimen shows a single, thin and parallel-sided septum or septal spine extending about one sixth of the radius of the calyx (Fig. 2A, B). Evidence of budding is shown by a scar in one specimen (Fig. 2E, I) and by buttressing of a second generation individual against the original calyx in cross-section (Fig. 2A).

Discussion. - The scarcity of septa within the calyx serves to delimit the Kyrgyz material from the type species, C. orientalis, which has 8 pairs of septa (Park et al. 2011). Of four available transverse sections, one shows no septal structures, two show a blunt spine or septum (Fig. 2F) and the fourth shows a single thin septum (Fig. 2A, B). Cambroctoconus orientalis also attains twice the height of C. kyrgyzstanicus, which may explain why many specimens illustrated by Park et al. (2011, fig. 1) become almost parallel-sided in the latest growth stages. The pores in the thecal wall of C. kyrgyzstanicus may be obscured by recrystallisation in the material at hand (Fig. 2D, H, J) and have not been detected in cross-sections.

Phylum Mollusca Cuvier, 1797

Class Helcionelloidea Peel, 1991

Order Helcionellida Geyer, 1994

Family Helcionellidae Wenz, 1938

\section{Genus Manasoconus Peel gen. nov.}

Type species. - Manasoconus bifrons Peel gen. et sp. nov.

Etymology. - Named after Manas, hero of the traditional Kyrgyz epic poem.

Diagnosis. - Isostrophic, open-coiled through about three-quarters of a whorl. Whorl cross-section sub-circular in earlier growth stages, uniformly convex, later expanding along the plane of symmetry ("antero-posteriorly") with little lateral increase. Early stages with prominent, acute, transverse costae separated by concave interareas, becoming restricted to the mid-dorsal area with increased growth. Later growth stages with a reticulation of widely spaced cords and growth lines, appearing first on the umbilico-lateral areas before later spreading across the entire dorsum.

Discussion. - The laterally compressed shell morphology is described but not common amongst helcionelloids (cf. Peel 1988, Resser 1939, Gubanov \& Peel 2001) where most species show a higher rate of shell expansion. Manasoconus is readily distinguished from other described taxa by its distinctive ornamentation. Both the costate and reticulate ornament patterns occur in other helcionelloids (e.g., Geyer 1986, Gubanov et al. 2004) but the ontogenetic change from prominent transverse costae to a reticulate pattern after about one third of a whorl is unique.

\section{Manasoconus bifrons Peel sp. nov.}

Figure 3A-D

Holotype. - Nearly complete conch under FG 596/XII/017b (Fig. 3A, B).

Type locality and horizon. - Sauk Tanga, FG locality 596/III/11, $40^{\circ} 01^{\prime} 33.4^{\prime \prime} \mathrm{N}, 70^{\circ} 16^{\prime} 18.3^{\prime \prime}$ E.; Alay range, western Kyrgyzstan, upper Amgan Stage.

Paratype. - Nearly complete conch under FG 596/XII/029a.

Etymology. - From the Latin bifrons, with two faces; a reference to the two contrasting styles of ornamentation.

Diagnosis. - As for genus.

Description. - Type species of Manasoconus gen. nov. in which the isostrophic shell forms an open coil of about three quarters of a whorl. Maximum length of the present specimens is $\mathrm{ca} 2.1$ to $2.6 \mathrm{~mm}$, max. width 0.8 to $1.1 \mathrm{~mm}$. 


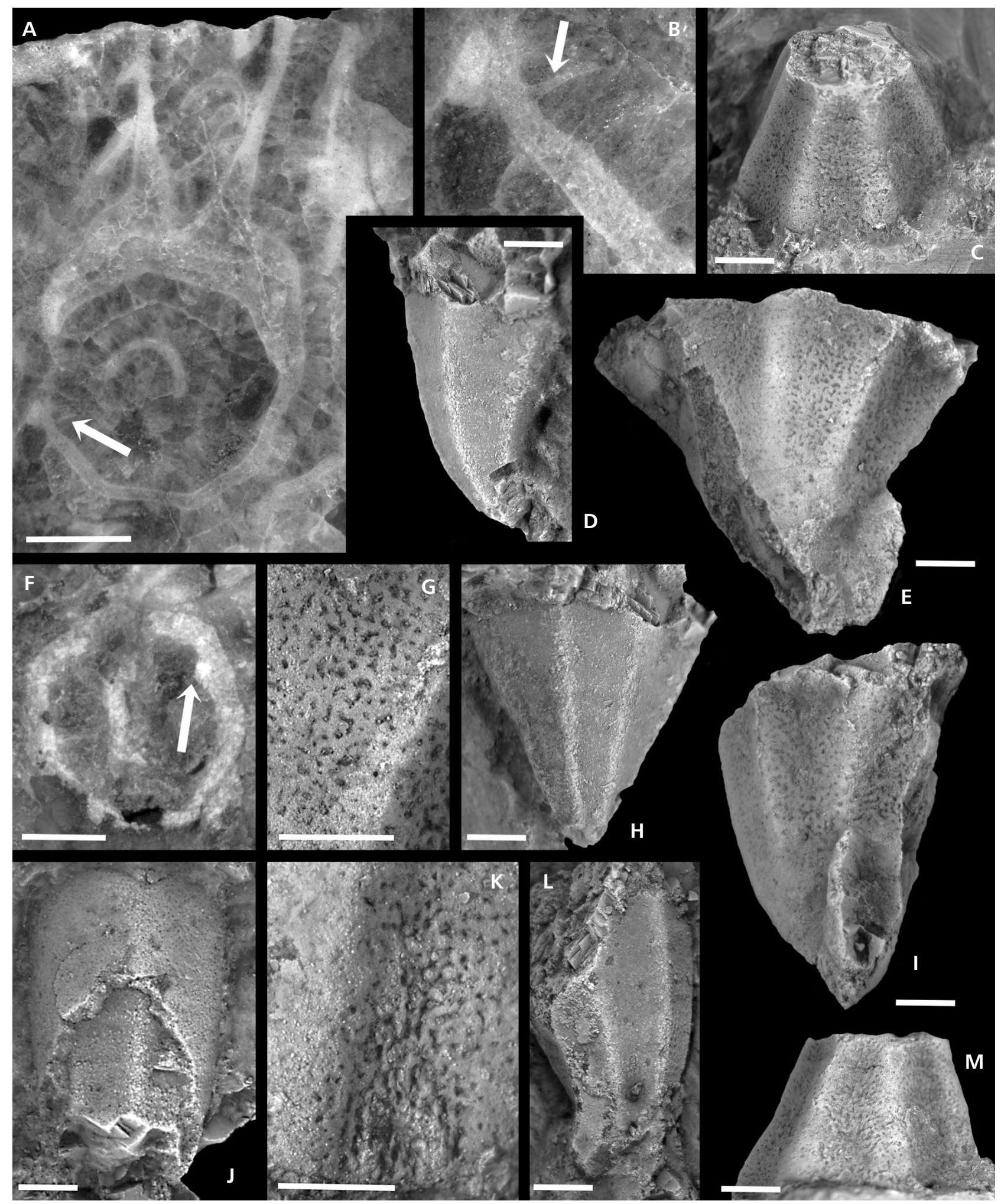

Figure 2. Cambroctoconus kyrgyzstanicus Peel sp. nov. • A, B - paratype, transverse polished section with thin septum (arrowed, see also B); a second buttressed calyx (A, top) in long section is seemingly budding from the first calyx, FG 596/XII/19a. $\bullet$ C, M - paratype, inverted calyx with broken early growth stages, in oblique (C) and lateral (M) views, FG 596/XII/007d. • D, H - paratype, FG 596/XII/022a. • E, G, I - holotype, note attachment scar $(\mathrm{H})$ and detail of porous surface (G), FG 596/XII/034a. - F - paratype, transverse section showing blunt spine or septum (arrow), FG 596/XII/001e. • J - paratype, partly exfoliated specimen with shell pores indicated by papillae on internal mould of calyx, FG 596/XII/020d. - K - paratype, detail of pores, FG 596/XII/007d. • L - paratype, FG 596/XII/020c. Scale bars $1 \mathrm{~mm}$. 


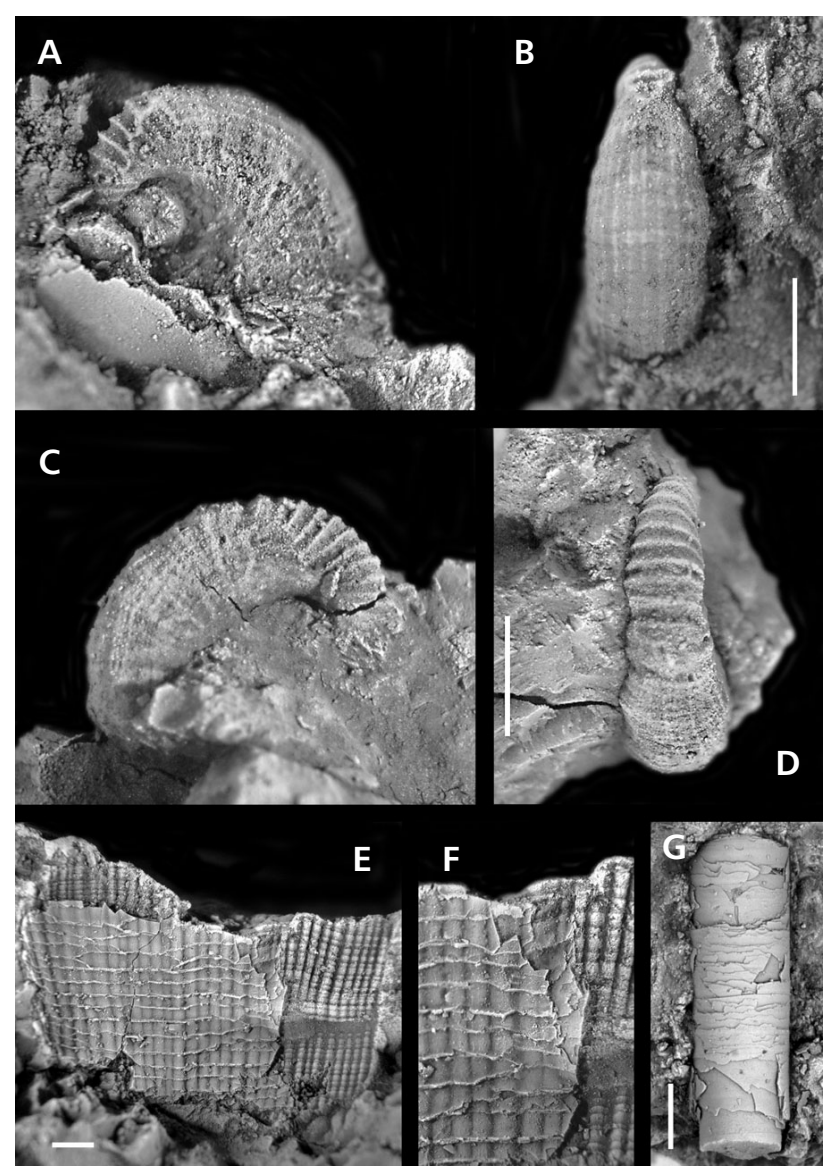

Figure 3. A-D - Manasoconus bifrons Peel gen. et sp. nov, Sauk Tanga locality; A, B - conch, internal mould, FG 596/XII/017b, lateral view and view of the abapical side of the whorl; C, D - conch, internal mould, holotype, FG 596/XII/029a, lateral view and view of the abapical side of the whorl. • E, F - Tesella sp., FG 596/XII/016b, entire specimen as preserved and detail. • G - Hyolithellus sp., FG 596/XII/004b, fragment of tube. All scale bars $1 \mathrm{~mm}$.

In the early growth stages, comprising about one third of a whorl, the cross-section is sub-circular and ornamented by prominent transverse costae separated by broad, concave, intercostal areas. Initially, the costae extend across the lateral and dorsal areas but gradually they become restricted to the dorsum as the aperture is approached, with lateral areas ornamented with the reticulate pattern characteristic of the late growth stage. The intersections of the longitudinal and transverse elements within the reticulate pattern create small and low nodes. A slight transverse constriction separates the two growth stages with the shell in the late growth stage initially continuing the slow expansion in width characteristic of the early growth stage before becoming parallel-sided. In lateral view, however, the whorl profile expands in the plane of symmetry such that the aperture at the latest preserved growth stage forms about four-fifths of the total length. A broad but very shallow median sinus is present in the later growth stages.
Discussion. - Manasoconus bifrons is distinguished from M. reticulata (Lermontova, 1940) from Shodymir in Fergana in having less prominent longitudinal cords in the reticulate pattern of the late growth stage. In M. reticulata the longitudinal cords dominate whereas longitudinal and transverse elements are more equally expressed in $M$. bifrons. Furthermore, the conspicuous transverse costae which are characteristic of the earliest stages of $M$. bifrons are not clearly discernible in the published illustrations of M. reticulata (Lermontova 1940, pl. 34, fig. 5; Lermontova 1951, pl. 3, fig. 14).

In terms of its lateral compression, Manasoconus bifrons resembles the late Middle Cambrian species from North Greenland described by Peel (1988) as Latouchella pearylandica but that species is more open coiled and lacks the characteristic reticulate ornamentation in the late growth stages. Ornamentation in Tichkaella Geyer, 1986 from the Middle Cambrian of Morocco is dominated by finer, more closely spaced spiral elements throughout growth, and the costate early growth stage is lacking (Geyer 1986). The Middle Cambrian species described by Resser (1939) from the Middle Cambrian of Idaho, USA, as Helcionella aequa is strongly laterally compressed, with a narrow dorsum, but the lateral sides are almost parallel. Its later stages carry a spiral/reticulate ornamentation similar to Tichkaella and the late stages of M. bifrons.

Phylum Arthropoda Siebold \& Stannius, 1848

Subphylum Trilobita Walch, 1771

?Order Redlichiida Richter, 1932

?Suborder Redlichiina Richter, 1932

?Family Ellipsocephalidae Matthew, 1887

\section{Genus Glabrella Lermontova, 1940}

Type species (by original designation). - Glabrella ventrosa Lermontova, 1940. Middle Cambrian, Amga Stage, Shodymir region, Turkestan Range, southern Fergana Basin.

Nomenclatural note. - The generic name Glabrella Lermontova, 1940 for Cambrian trilobites is a junior homonym of Glabrella Scudder, 1882, introduced for extant molluscs. However, Scudder's name is a nomen nudum based on an unpublished manuscript by the Austrian scientist Carl Megerle.

Discussion. - Lermontova (1940, 1951) described and figured the fairly smooth and highly convex cranidium of Glabrella ventrosa with short, distinctly upturned palpebral lobes. The pygidium from the type material and subsequently described material equate with the specimens presented herein, which have a clearly smaller convexity. Lermontova (1940, p. 120) compared the cranidia with 


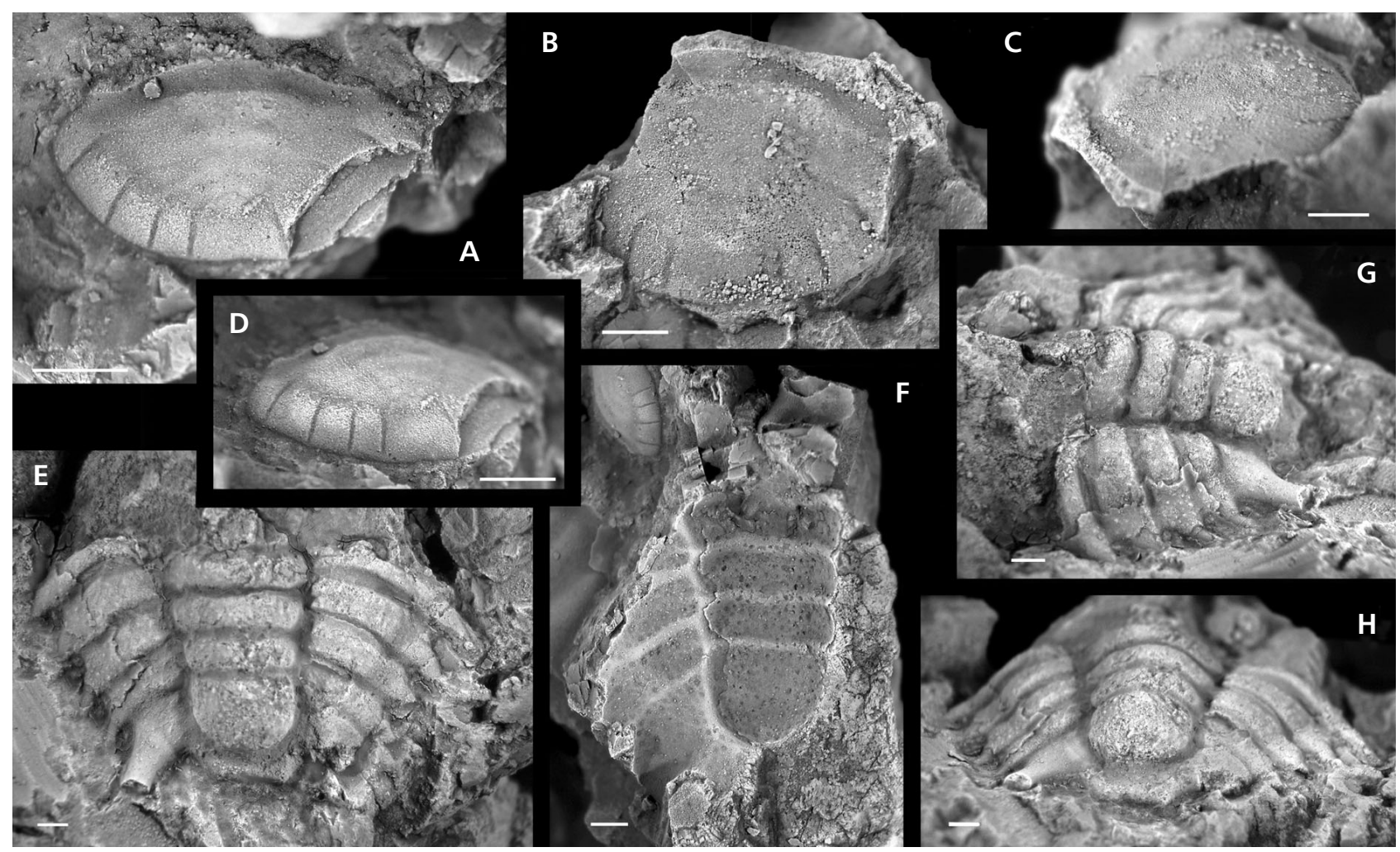

Figure 4. A-D - Glabrella ventrosa Lermontova, 1940, Sauk Tanga locality. $・$ A, D - pygidium, internal mould, partly broken and exhibiting ventral doublure, FG 596/XII/018b; A - dorsal view; D - oblique posterior view. • B, C - incomplete pygidium, internal mould, FG 596/XII/014a; B - dorsal view; C - slightly oblique lateral view. Scale bar $1 \mathrm{~mm}$. E-H - Dorypyge richthofeniformis Lermontova, 1940, Sauk Tanga locality; E, G, H - pygidium, partly exfoliated, FG 596/XII/001a. E - dorsal view; G - left lateral view; H - posterior view. $\bullet \mathrm{F}$ - incomplete pygidium, partly exfoliated, ventral view external mould, FG 596/XII/018a, together with pygidium of Glabrella ventrosa shown in Fig. 4A and 4D. Note infilling of a central canal in the coarse granules. Scale bar $1 \mathrm{~mm}$.

those of Pagetiellus Lermontova, 1940 and thus placed the genus among the (at that time appropriate) Family Pagetidae [sic!] Kobayashi, 1935. However, the pygidium clearly excludes Glabrella from the Hebediscidae Kobayashi, 1944 as now used and the Eodiscoidea in general.

Jell \& Adrain (2002) obviously acknowledged the similarity of the cranidium with those known from Kingaspis Kobayashi, 1935 and placed Glabrella under the Family Ellipsocephalidae Matthew, 1887. The pygidium is clearly distinguished from any pygidium known from unequivocal genera of the Ellipsocephalidae. However, some resemblance can be seen in the pygidium of Ellipsocephalus hoffi Schlotheim, 1823 from the lower Middle Cambrian Jince Formation of Bohemia. This species has a pygidium with a poorly subdivided, tapering rhachis reaching nearly to the posterior margin, to probably the position of the obsolescent border furrow, and smooth pleural areas (e.g., Geyer 1990, pl. 14, figs 1b, 2c, 3). The upturned, rope-like palpebral lobes in Glabrella ventrosa are clearly different from the palpebral lobes in the superficially similar species of Kingaspis, which has transversely weakly convex, blade-like palpebral lobes. However, somewhat upturned, but less rope-like palpebral lobes are again seen in
Ellipsocephalus. For the moment, the placement under the Ellipsocephalidae appears to be poorly constrained by apomorphic characters, but the most parsimonious solution for the systematic relationship of Glabrella.

\section{Glabrella ventrosa Lermontova, 1940}

Figure 4A-D

1940 Glabrella ventrosa, Lerm. (MS); Lermontova, p. 120, pl. 35, fig. 9, 9a-9d.

1951 Glabrella ventrosa Lermontova. - Lermontova, pp. 28-29, 36, pl. 2, figs 1-4.

1975 Glabrella ventrosa Lermontova, 1940. - Repina et al., pp. 102-103, pl. 8, figs 8-13.

2002 Glabrella ventrosa Lermontova, 1940. - Jell \& Adrain, p. 378.

Type material. - From Shodymir region, Turkestan Range, southern Fergana Basin.

Material. - Two pygidia, FG 596/XII/014a and FG 596/XII/018b. 
Description. - Pygidium a shallow convex, lenticular to transversely subelliptical body, ratio length/width $\mathrm{ca} 55$ percent (inclusive articulating half-ring), maximum transverse width across anterior axial ring. Axis weakly convex, poorly defined from pleural areas, longitudinally lancet-shaped, with $\mathrm{ca} 45$ percent maximum pygidial width across first axial ring, and of $c a 85$ percent pygidial length (including articulating half-ring); consisting of four axial rings and a terminal axial piece. Axial rings separated by feebly imprinted, but broad axial furrows, with slightly more elevated lateral portions resulting in a nearly flat or even somewhat sunken sagittal line. Terminal axial piece a diamond-shaped low pad with subrounded corners, particularly the anterior margin defined by gently curved low and narrow furrow. Posterior rim of terminal axial piece reaches posterior border. Articulating furrow sagittally broad and curved, moderately deep, articulating half-ring sagittally very narrow, merely collar-like, raised from the articulating furrow. Pleural areas barely convex (tr.), slightly sunken between axis and margin, defined by narrow, shallow and with interpleural furrows and obsolescent pleural furrows. Pygidial lateral and posterior border relatively wide, subequal in breadth throughout, defined by a shallow to obsolescent border furrow which is as well a change in convexity. Four well developed, moderately deep, sharply defined furrows perpendicular to the margin mark the segmental boundaries, the posteriormost of which corresponds with the boundary between the terminal axial piece and the adjacent axial ring. Lateral and posterior margins composed of two gentle arches separated by a tr. wide and very shallow median indenture. Ventral doublure a broad and almost flat blade (Fig. 4A, D). Entire surface of pygidium smooth.

Discussion. - The pygidia from Sauk Tanga compare perfectly those from the type lot. For differential diagnosis from Glabrella babakovica Repina, 1960 and G. mrassina Egorova, 1962 see Repina (1960, p. 157) and Egorova (1962), respectively. Glabrella? pitans Palmer \& Gatehouse, 1972 shows only superficial similarities and belongs to a separate genus.

The species has already been found in the Sauk Tanga canyon area, listed in Repina et al. (1975, p. 103) under their locality 27 . This locality is possibly identical with the locality from which the herein described material originated, but the information provided by Repina et al. (1975) is insufficient for a precise location.

Order Corynexochida Kobayashi, 1935

Family Dorypygidae Kobayashi, 1935

\section{Genus Dorypyge Dames, 1883}

Type species (by original designation). - Dorypyge rich- thofeni Dames, 1883 from the Middle Cambrian Changhia Formation, Liaoning Province, North China Platform.

\section{Dorypyge richthofeniformis Lermontova, 1940}

Figure 4E-H

1940 Dorypyge richthofeniformis Lerm. (MS). - Lermontova, p. 141, pl. 44, fig. 2, 2a-2c.

1951 Dorypyge richthofeniformis Lermontova. - Lermontova, pp. 11-12, 36, pl. 1, figs 1-5.

1973 Dorypyge richthofeniformis Lermontova. - Khayrullina, p. 53, pl. 4, figs 1-3.

1975 Dorypyge richthofeniformis Lermontova, 1940. - Repina et al., pp. 142-143, pl. 21, figs 2-7.

? 2009 Dorypyge richthofeniformis Lermontova, 1940. Ghobadi Pour \& Popov, pp. 1046-1048, figs 2N-Q, $4 \mathrm{~A}-\mathrm{U}$.

Type material. - From Shodymir region, Turkestan Range, southern Fergana Basin.

Material. - Two incomplete pygidia, FG 596/XII/001a and FG 596/XII/018a (incomplete external mould); partial thoracic segment attributed to Dorypyge richthofeniformis under FG 596/XII/015a.

Description. - Pygidium with maximum transverse width across anterolateral corners. Axis with $\mathrm{ca} 35$ percent maximum pygidial width across first axial ring and of more than 80 percent pygidial length (except for articulating half-ring); consisting of three axial rings and a terminal axial piece of $\mathrm{ca} 75$ percent tr. width of anteriormost pygidial axial ring. Axial rings distinctly convex (sag. and exsag.) with slightly swollen lateral portions, separated by fairly broad (sag. and exsag.) furrows. Terminal axial piece with semicircular posterior margin, composed of a posterior spherical section and an anterior cylindrical section separated by an obsolescent transverse furrow. Articulating half-ring not entirely preserved in the present material, obviously sag. narrow but distinctly convex, transversely convex and well raised from articulating furrow. Posterior end of rhachis defined by shallow border furrow. Pleural areas moderately convex (tr.), sloping towards border furrow, defined by five well impressed, but progressively somewhat shallower and narrower pleural furrows and with faint interpleural furrows. Pleurae develop across lateral border furrow into fairly long, slender, acute and posterolaterally directed spines. Spines at subterminal segment (corresponding to anterior part of terminal axial piece) conspicuously enlarged, somewhat curved upward, subelliptical in cross-section. Lateral border furrow a broad band creating shallow depressions between pleural areas and bases of the lateral spines, intersected by extensions of pleural furrows. Posterior border a narrow, weakly 
convex blade with a pair of stout corners posterior to the axial furrows.

Entire carapace with irregularly spaced low, coarse and moderately coarse granules.

Discussion. - Material assigned to Dorypyge richthofeniformis has recently been described from the Arpatektyr Mountains in the northern foothills of the Akai Range, Kyrgyzstan (Ghobadi Pour \& Popov 2009). This material includes silicified sclerites of relatively small specimens with clearly prevailing characters of immature individuals, such as the arrangement of coarse granules into transverse rows on the pygidial axial rings, narrow and weakly convex pleurae and marginal spines separated by acute angles at the lateral margin. Although the preserved features of this material fit into the general set of characters of Dorypyge richthofeniformis, the absence of adult specimens does not allow a confident assignment to this species. In addition, the fauna described by Ghobadi Pour \& Popov (2009) appears to belong to the Pseudanomocarina Zone and would thus represent a younger age than the specimens described under D. richthofeniformis to date.

\section{Genus Olenoides Meek, 1877}

Type species (by original designation). - Paradoxides? nevadensis Meek, 1877 from the Middle Cambrian Wheeler Formation, Utah, U.S.A.

Discussion. - The primary features for specific identification within the genus Olenoides are the number of axial rings and pairs of marginal spine pairs in the pygidium. In addition, the development of interpleural furrows of the pygidium is a helpful criterion.

\section{Olenoides sagittatus Geyer sp. nov.} Figure 5A-Q

Holotype. - Fairly complete pygidium, FG 596/XII/010a (Fig. 5C, F, I).

Type locality and horizon. - Sauk Tanga, FG locality 596/III/11, 40 01'33.4” N, 70 16'18.3” E.; Alay range, western Kyrgyzstan, upper Amgan Stage.

Paratypes. - Three incomplete cranidia and cranidial fragments under FG 596/XII/005a, FG 596/XII/011b and FG 596/XII/019a (external mould); librigena under FG 596/XII/012a; eight incomplete pygidia and pygidial fragments under FG 596/XII/002a, FG 596/XII/005b, FG 596/XII/006c, FG 596/XII/007a, FG 596/XII/008a, FG 596/XII/011a, FG 596/XII/013d, and FG 596/XII/016a; partial thoracic segments attributed to Olenoides sagittatus under FG 596/XII/002b, FG 596/XII/008b, and FG 596/XII/012f.

Etymology. - From Latin sagitta, arrow, and sagittatus, with arrows; a reference to the characteristic shape of the pygidial pleural ribs.

Diagnosis. - Species of Olenoides with narrow anterior border swinging around frontal lobe, nearly pinches out medially; lateral glabellar furrows S1 clearly bifurcate, S2 less so. Pygidium with considerably tapering rhachis, terminal axial piece narrow (sag.); four pairs of long, fairly slender marginal spines the terminal pair of which is separated by a considerable distance; interpleural furrows form triangular areas with a posteriorly shallowing margin, extending as an almost thread-like narrow band towards the base of the corresponding marginal spine.

Description. - Cephalon and glabella with typical dorypygid shape. Glabella more than 95 percent cephalic length, with subparallel sides or faintly growing in width from the occipital furrow to S3; with moderately well developed kootenioid constriction in front of S3; frontal lobe with moderate curvature anteriorly, reaching to the anterior border furrow, with faint anterolateral corners, from which the eye ridges originate as shallow backwardly crooked lobes; three pairs of lateral glabellar furrows developed, all characterised by the absence of the surface prosopon: S1 formed by transverse and then strongly backwardly arched shallow furrows, commence distant from axial furrows, a faint bifurcation indicated at the backward curvature; S2 a shallow, moderately long and faintly backwards curved depression commencing distant from axial furrow; S3 short and faint, transversely directed depressions well distant from axial furrow; S4 apparently indicated as small, obsolescent and poorly defined depressions. Occipital furrow consists of deeply incised distal portions connected by a moderately deep median section. Occipital ring of $c a$ 18-19 percent cephalic length, tr. gently convex, with shallow sagittal curvature, lenticular in outline with moderately curved lateral sections and a almost straight median section of the posterior margin, expanding laterally into anterolaterally pointing projections that have a faint connection with the posteroproximal corners of the fixigenae.

Eye lobe moderately long, exsagittal length $\mathrm{ca} 28$ percent cephalic length, nearly parallel to axis, located with centre in transverse line with posterior half of L2, palpebral furrow shallow, but well visible, with faint curvature; eye ridge almost straight, low, but forming posterior margin of steeply sloping preocular areas, defined from eye lobes by shallow and poorly defined depression, directed strongly forward to axial furrow opposite posteriormost part of L4 to extend into narrower and low, s-shaped lobes towards 
anterolateral corners of the glabella. Fixigenae with shallow to moderate convexity in transverse section, moderately convex exsagittally, with steep slope towards posterior border furrow, subtrapezoidal in outline, extended into acute, strongly deflected posterolateral projections.

Anterior border very narrow (sag.) and thread-like in front of the glabella, moderately curved, broadening anterior to axial furrows and faintly growing in exsag. width towards facial sutures. Anterior border furrow a very narrow (sag. and exsag.) incision anterior to the glabella, moderately wide and relatively shallow in front of the preocular fields. Genal field steeply inclined and thus narrow in dorsal view. Posterior border convex, narrow proximally, broadening distally from a narrow section at axial furrows to a maximum just proximal to the line of the palpebral furrow, then less convex and with a slight forward curvature of the posterior margin. Posterior border furrow well-defined, moderately broad and moderately deep, more-orless straight in the proximal portion, with a slight broadening anteriorly close to the facial suture. Anterior branch of facial suture almost straight and slightly adaxially directed from the anterior ends of the visual surface, curved slightly inward when reaching anterior border. Posterior branch of the suture long, directed obliquely outward, rapidly swinging backward to create large posterolateral projections.

Librigena with fairly wide (tr.), weakly to moderately raising ocular platform with very narrow, collar-like and nearly vertical basal strip of eye platform; lateral border relatively narrow anteriorly, growing to moderate width (tr.) rearward; lateral border furrow shallow, weakly defined; lateral border extends into moderately long genal spine with broad base. Doublure corresponds to the lateral border in the rearward growing width.

Thorax known only from fragments of thoracic segments. Pleurae subequal in exsag. breadth along their course, with a faint geniculation at about midlength and with large ventrally deflected facet. Pleural furrows moderately deep, deepest near axial furrow, slightly backward directed from there, with a slight curvature, fading at the base of the pleural spines. Pleural spines long, falcate, gently curved posterolaterally, clearly separated from pleural base by the termination of the anterolateral facet and a small swelling at the posterior margin.

Pygidium subsemicircular with four pairs of strong marginal spines. Rhachis moderately to strongly convex in transverse section, composed of three axial rings and a composite terminal axial piece plus a narrow articulating half-ring. Axial rings distinctly convex (sag. and exsag.) with lateral swollen portions defined from middle portion by shallow furrows obsolescent in the central (exsag.) part of its course and a slight change in convexity, each ring with a strong node in a slightly posteromedian position; terminal axial piece with sag. narrow section with gently curved posterior margin, and an anterior cylindric section separated by a pair of elongate shallow depressions, with median node on the posterior section; axis (except for articulating half-ring and spines) of $c a 82$ percent pygidial length; width across anterior axial ring $c a 38$ percent pygidial width at anterolateral corners; width across terminal axial piece almost 60 percent width across anterior axial ring. Articulating half-ring sag. narrow, well raised above articulating furrow. Articulating furrow well incised, moderately wide; furrow between axial ring 1 and 2 similar to articulating furrow, moderately wide and moderately deep, furrow between axial ring 2 and 3 moderately wide, slightly narrower and shallower than anterior furrow, furrow between axial ring 3 and terminal axial piece narrow and relatively shallow. Posterior end of rhachis defined by slightly sunken area in front of posterior border.

Pleural areas moderately convex (tr.), sloping towards border furrow, defined by well impressed, but progressively narrower pleural and interpleural furrows; interpleural furrows developed as triangular areas with a posteriorly shallowing margin. This triangular shape, which is particularly well developed in the anterior two segments, creates the characteristic arrow-shape of the posterior ribs on each segment, extending as an almost thread-like narrow band towards the posterior base of the corresponding marginal spine. Anterior ribs form roughly lancet-shaped areas, which are nearly separated from the lateral border on internal moulds. Four pairs of marginal spines, each long, slender, acute, posterolaterally directed. Terminal pair of spines commences almost posterior to axial furrows, strongly backward directed, separated by a considerable distance and forming a broadly parabolic course of the posterior margin. Posterior border moderately broad (sag.) and moderately convex, slightly broader than lateral border and thus with a faint forward curvature behind the terminal

Figure 5. Olenoides sagittatus Geyer sp. nov., Sauk Tanga locality. • A, B, D, E, G - paratype, incomplete cranidium, partly exfoliated, FG 596/XII/011b. A - dorsal view; B - dorsal view, detail of fixigena and eye ridge showing pattern of terrace ridges; D - posterior view; E - dorsal view, detail of anterior part of glabella with pattern of terrace ridges; $\mathrm{G}-$ left lateral view. $\bullet \mathrm{C}, \mathrm{F}$, I - holotype, incomplete pygidium, FG 596/XII/010a, internal mould, dorsal, lateral and posterior views. $\bullet \mathrm{H}$ - paratype, fragment of pygidium, internal mould, FG 596/XII/016a. $\bullet \mathrm{J}-$ paratype, fragment of thoracic segment, internal mould, FG 596/XII/008b. $\bullet$ K - paratype, incomplete pygidium, internal mould, FG 596/XII/011a. $\bullet$ L - paratype, incomplete pygidium, FG 596/XII/008a. • M, O, P - paratype, incomplete pygidium, internal mould, FG 596/XII/007a; M - posterior view; O - dorsal view with exposed mould of ventral doublure; $\mathrm{P}$ - lateral view, together with cranidium of Olenoides sp. A. $\bullet \mathrm{N}$ - paratype, fragment of thoracic segment, internal mould, FG 596/XII/002b. • Q - paratype, librigena, FG 596/XII/012a, ventral view, together with fragment of thoracic pleura. Scale bar 1 mm. Dorsal views unless otherwise stated. 





axial piece. Lateral border moderately convex, strongly rhythmic due to the intersection from the pleural areas; lateral border furrow consisting of separated depressions in continuation of the pleural and interpleural furrows. Doublure more-or-less corresponding to the lateral border (Fig. 5O).

Cranidial external surface except for furrows entirely covered by fingerprint-type terrace ridges which are modified to small elliptical crests on the lateral portions of the occipital ring, on the posterior border and on the anterior and posterior convex parts of the fixigenae.

Discussion. - Olenoides sagittatus is best characterised by its delicate furrow pattern of the pleural fields, by its four pairs of slender, obliquely outward and rearward directed spines with the broad paraboloid shape of the margin between the terminal pair of spines, and the distinctly tapering pygidial axis with the narrow terminal axial piece. No other species of Olenoides has this combination of characters. The cephalon is only known from fragmentary material and is incompletely recorded. However, the swinging course of the narrow and medially nearly fading anterior border is also an unusual character among the species of Olenoides.

A somewhat similar species of Olenoides has been briefly described from the Shodymir section of the southern Fergana area under the name "Neolenus (= Olenoides) inexpectans Lerm. (MS)" (Lermontova 1940, p. 138, pl. XLII, fig. 6, 6a-6c). The three figured cranidia and the only figured pygidium are more or less complete, but relatively unfavourably preserved, and the smallest of the three cranidia appears to belong to a different species. In any case, among the recognisable characters the cranidia appear to have a flatter anterior margin of the glabella and a less swinging anterior border; the pygidium of $O$. inexpectans is clearly differentiated by a broader and less tapering rhachis, more stout and more strongly rearward directed marginal spines, and a shorter distance between the terminal pair of marginal spines.

The cranidium of Olenoides sagittatus shows some resemblance to Olenoides procerus Tomashpolskaya, 1971 (in Chernysheva 1971, pl. 13, figs 4-6) from the lower Middle Cambrian Suyarik "horizon" of the Batenev range of the Altay-Sayan fold-belt. It has a similar pattern of the lateral glabellar furrows and the course of the anterior border. However, the anterolateral grooves in the glabella are more distinct in $O$. procerus, and the fixigenae are slightly wider. In addition, pygidia are unknown from $O$. procerus. Another similar species, described as Olenoides erbiensis Tomashpolskaya, 1971 (in Chernysheva 1971, pl. 13, figs 1-3), also from the Suyarik "horizon" of the Batenev range, has S1 as more strongly developed depressions, shorter palpebral lobes in a slightly more anterior position, a less arched anterior margin and a shallower curvature of the frontal lobe. Pygidia are also undescribed from this species.
The characteristic pattern of pleural furrows and the rhachis in the pygidium of Olenoides sagittatus is comparable to those on the pygidia of $O$. optimus Lazarenko, 1954. However, the cranidia are easily distinguished by the shape of the glabella, the pattern of lateral glabellar furrows, the length of the eye lobes and a large occipital spine.

\section{Olenoides sp. A}

Figure 6A-E

Locality. - Sauk Tanga, FG locality 596/III/11; $40^{\circ} 01^{\prime} 33.4^{\prime \prime} \mathrm{N}, 70^{\circ} 16^{\prime} 18.3^{\prime \prime} \mathrm{E}$.

Material. - Two incomplete cranidia and cranidial fragments under FG 596/XII/007b and FG 596/XII/033a; incomplete pygidium under FG 596/XII/013c.

Description. - Cephalon and glabella with typical dorypygid shape. Glabella $c a 95$ percent cephalic length, sides faintly growing in width from the occipital furrow to S3; with weakly developed kootenioid constriction in front of S3; frontal lobe with moderate curvature anteriorly, reaching to the anterior border furrow, with faint anterolateral corners; three pairs of lateral glabellar furrows developed: S1 with nearly transverse well impressed lateral section, then with bifurcation into a narrow and shallow, but relatively extended posterior branch and an obliquely anteriorly directed, fairly wide but short anterior branch, commences at axial furrows; $\mathrm{S} 2$ a shallow, moderately long and slightly backwards curved furrow commencing at axial furrow, with faint and very short bifurcation adaxially; S3 a shallow but well visible, transversely directed furrow commencing at axial furrow and extending nearly to axis; close to the base of S3 starts a faint to obsolescent fairly broad furrow, which is obliquely forward directed. Occipital furrow consists of deeply incised and long distal portions connected by a slightly shallower, short median section. Occipital ring of probably $\mathrm{ca} 18$ percent cephalic length, tr. gently convex, with considerable sagittal curvature, lenticular in outline with moderately curved lateral sections; median section of the posterior margin not preserved in the present material.

Eye lobe, palpebral furrow, and anterior part of fixigena not preserved in the present material; base of eye ridge indicates steeply backward directed course from just anterior to S3, extends from there into very thin and low, s-shaped lobes which traverse axial furrow and fuse with anterolateral corners of the glabella. Fixigenae with shallow to moderate convexity in transverse section and with steep slope towards posterior border furrow, apparently subtrapezoidal in outline.

Anterior border extremely narrow (sag.) and blade-like 



Figure 6. A-E - Olenoides sp. A, Sauk Tanga locality. • A, B, D - partial cranidium, exfoliated, FG 596/XII/007b; A - dorsal view; B - electronically mirrored and merged to exemplify the morphology of the glabella; D - lateral view. $\bullet$ C - partial pygidium, FG 596/XII/013c, dorsal view. $\bullet$ E - fragment of cranidium, largely exfoliated, FG 596/XII/033a, dorsal view. - F-I - Kootenia sp. A, Sauk Tanga locality. • F, I - incomplete pygidium, FG 596/XII/003a, dorsal and posterior views. $\bullet \mathrm{G}$ - fragment of thoracic segment, FG 596/XII/010b, dorsal view. $\bullet$ H - incomplete cranidium, latex cast of shell interior, FG 596/XII/001h, dorsal view. Scale bar $1 \mathrm{~mm}$.

in front of the glabella, moderately curved, broadening and with a change in the curvature of the anterior margin anterior to axial furrows and almost constant in exsag. breadth towards facial sutures. Anterior border furrow a narrow (sag. and exsag.) incision anterior to the glabella, a moderately wide and shallow depression abaxially and poorly defined from preocular fields. Genal field steeply inclined and thus relatively narrow in dorsal view. Posterior border convex, narrow proximally, not visible in the distant portions in the present material. Posterior border furrow well-defined, moderately broad and moderately deep. Anterior branch of facial suture known only for the anteriormost part, curved slightly adaxially when reaching anterior border and cutting the border for a considerable distance. Posterior branch not visible in the present material.
Pygidium apparently subsemicircular, with four pairs of marginal spines. Rhachis strongly convex in transverse section, composed of four axial rings and a small terminal axial piece. Axial rings distinctly convex (sag. and exsag.), each ring with a strong node in a slightly posteromedian position; terminal axial piece sag. very narrow with gently curved posterior margin, forms a posterior appendage of the axial ring posterior to it, separated by a shallow, poorly defined slightly curved furrow with a pair of weak depressions; width across terminal axial piece roughly half width across anterior axial ring. Furrow between axial ring 1 and 2 moderately wide and moderately deep, furrow between axial ring 2 and 3 similar to anterior furrow, furrow between axial ring 3 and axial ring 4 narrow and relatively shallow. Posterior end of rhachis defined by very shallow, poorly defined posterior border furrow. 
Pleural areas moderately convex (tr.), sloping towards border furrow, defined by well impressed, but progressively narrower pleural furrows and interpleural furrows; interpleural furrows developed as triangular areas the shape of which creates narrow, posterolaterally narrowing posterior ribs on each segment, extending in threadlike narrow bands towards the posterior base of the marginal spines. Anterior ribs form broader, elongate and slightly curved areas extending into the marginal spines. Marginal spines apparently long, slender, acute, posterolaterally directed. Terminal pair of spines broader (tr.) at base, located posterior to axial furrows, well separated and forming a broadly parabolic course of the posterior margin. Posterior border moderately broad (sag.) and weakly convex, tends to form an obsolescent plectrum posterior to the rhachis. Lateral border low, rhythmic due to the intersection from the pleural areas; lateral border furrow merely depicted as a change in slope, consisting of separated depressions in continuation of the pleural and interpleural furrows.

Entire carapace smooth.

Discussion. - The sparse material in the sample does not allow a precise determination. Characters of the cranidium in particular indicate distinct differences from Olenoides sagittatus sp. nov. These characters include (i) the pattern of the lateral glabellar furrows; (ii) the connection between eye ridges and frontal lobe; (iii) the course of the anterior border; and (iv) the shape of the occipital ring and its connection with the fixigenae. In additions, the pygidium is distinguished from that of $O$. sagittatus mainly by differences in the pleural furrows and the shape and course of the posterior border.

The specimens described herein show some resemblance to Olenoides calvus Lazarenko, 1954, but can be easily distinguished by tr. wider fixigenae.

\section{Genus Kootenia Walcott, 1889}

Type species (by original designation). - Kootenia dawsoni Walcott, 1889 from the Middle Cambrian Stephen Formation of British Columbia, Canada.

\section{Kootenia sp. A}

Figure 6F-I

Locality. - Sauk Tanga, FG locality 596/III/11; $40^{\circ} 01^{\prime} 33.4^{\prime \prime} \mathrm{N}, 70^{\circ} 16^{\prime} 18.3^{\prime \prime} \mathrm{E}$.

Material. - Incomplete cranidia (external moulds) under FG 596/XII/001h and FG 596/XII/033a; incomplete pygidium under FG 596/XII/003a; fragment of thoracic segment under FG 596/XII/010b.
Description. - Cranidium only represented by a fragment of an internal mould showing part of the glabella, a partial fixigena, eye ridge and palpebral lobe. The visible details display the middle part of a typical glabella with the slight constriction at S3 and three pairs of lateral glabellar furrows. The fixigena is moderately convex and of a relatively narrow subcircular outline. The eye ridges have short transverse section near the axial furrow and then directed obliquely backward from a small node to proceed into the palpebral lobe, distinguished from them by a very shallow depression. Palpebral lobe narrow, weakly elevated above the broad and shallow palpebral furrow, which is poorly defined from the fixigena.

Pygidium subsemicircular with four pairs of strong marginal spines. Rhachis moderately to strongly convex in transverse section, composed of three axial rings and a composite terminal axial piece plus a very narrow articulating half-ring; each axial ring with a strong node in a slightly posteromedian position; terminal axial piece with sag. narrow section with gently curved posterior margin, and an anterior cylindric section separated by an obsolescent transverse furrow, the anterior section with median node; axis (except for articulating half-ring and spines) of ca 80 percent pygidial length; width across anterior axial ring ca 35 percent pygidial width at anterolateral corners; width across terminal axial piece $c a 68$ percent width across anterior axial ring. Articulating half-ring not entirely preserved in the present material, sag. very narrow and blade-like, well raised above articulating furrow. Articulating furrow well incised, moderately wide, furrow between axial ring 1 and 2 broad and moderately deep, furrow between axial ring 2 and three moderately wide, slightly shallower than anterior furrow, furrow between axial ring 3 and terminal axial piece narrow and shallow. Posterior end of rhachis defined by shallow border furrow.

Pleural areas moderately convex (tr.), sloping considerably towards border furrow, defined by five well impressed, but progressively narrower pleural furrows and with shallow, weakly defined oblique interpleural furrows. Pleurae develop across lateral border furrow into fairly long, stout, acute and posterolaterally directed spines. Terminal pair of spines posterior to axial furrows steeply backward directed, well separated, forming a broadly parabolic course of the posterior margin. Posterior border a fairly broad (sag.) moderately convex pad with a faint forward curvature behind the terminal axial piece so that the posterior border furrow is slightly narrower behind the axis' tip. Lateral border moderately convex; lateral border furrow a moderately broad and wavy band with depressions between pleural areas and bases of the lateral spines, intersected by extensions of pleural furrows.

Entire carapace smooth.

Discussion. - The fragments of a single cranidium and a single pygidium of a species of Kootenia are too incomplete 
to allow a precise determination. Remarkably, all of the $\mathrm{Ko}$ otenia species reported from the Turkestan and Alay ranges (Kootenia asiatica Kobayashi, 1935; Kootenia ontoensis Chernysheva, 1961; Kootenia bolgovae Repina, 1975) are clearly distinguished from the form from Sauk Tanga by at least five segments visible in the pygidial rhachis and none of them appears to have a close relationship with it.

Order Ptychopariida Swinnerton, 1915

?Family Agraulidae Raymond, 1913

\section{Genus Pseudoeteraspis Chernysheva, 1950}

Type species (by original designation). - Pseudoeteraspis angarensis Chernysheva, 1950 from the Middle Cambrian of the Prianabar region, Siberia.

\section{Pseudoeteraspis? sp. A}

Figure 7A, B

Locality. - Sauk Tanga, FG locality 596/III/11; $40^{\circ} 01^{\prime} 33.4^{\prime \prime} \mathrm{N}, 70^{\circ} 16^{\prime} 18.3^{\prime \prime} \mathrm{E}$.

Material. - Single incomplete cranidium (external mould) under FG 596/XII/031b.

Description and discussion. - This trilobite species is only present in the sample as a very incomplete fragment of a cranidium preserved as an external mould. The specimen is too brittle to reliably allow the preparation of a cast so that the photo (Fig. 7B) is electronically inverted from that of the external mould. Visible are the anterior two-thirds of a forward tapering glabella with a slight change in the course of the lateral sides and the axial furrow. It also displays the relatively weak convexity and the absence of well recognizable lateral glabellar furrows together with a shallow curvature of the frontal lobe. The glabellar front reaches to the anterior border furrow in front of which part of a raised and padded anterior border of considerable sag. breadth can be seen. The preserved parts of the fixigenae show raised smooth and moderately convex areas, which do not show clear signs of eye ridges in front.

Discussion. - These visible characters indicate a high degree of similarity with species described under the genus Pseudoeteraspis, such as $P$. aldanensis Chernysheva, 1950. This species was described from the Prianabar region and the Aldan Anticline of Siberia and used as an index fossil of the Pseudoeteraspis-Parapoliella-Namanoia Zone, which would be considerably older than the upper Amgan age indicated by well determinable fossils. However, distinct differences exist, e.g., in the lower convexity of the glabella of the Sauk Tanga specimen.



Figure 7. Pseudoeteraspis? sp. A, Sauk Tanga locality. • A - partial cranidium, external mould, FG 596/XII/031b. • B - same specimen, electronically inverted photo, slightly enhanced. Scale bar $1 \mathrm{~mm}$.

Phylum Brachiopoda Dumeril, 1806

Subphylum Rynchonelliformea Williams, Carlson,

Brunton, Holmer \& Popov, 1996

Class Kutorginata Williams, Carlson, Brunton, Holmer \& Popov, 1996

Order Kutorginida Kuhn, 1949

Family Nisusiidae Walcott \& Schuchert in Walcott, 1908

\section{Genus Narynella Andreeva, 1987}

Type species (by original designation). - Nisusia ferganensis Andreeva, 1962, Middle? Cambrian (see Remarks below), Fergana Basin, Kyrgyzstan.

Discussion. - The family Nisusiidae as defined by Popov \& Williams (2000) includes five genera of which $\mathrm{Ni}$ susia Walcott is by far the most common and diverse. Bell (1941) recognised two morphotypes within Nisusia defined by the shape of its ventral valve and the external ornamentation of the shell. The first type is represented by spinose costellate species of Nisusia with a conical ventral valve [e.g., the type species $N$. festinata (Billings, 1861)], the second type by costellate species lacking spines and having a ventral valve that is convex in lateral profile (e.g., N. montanaensis Bell, 1941). Bell (1941) suggested that the two morphotypes might represent separate genera.

Andreeva (1987) described new genus Narynella, with Nisusia ferganensis Andreeva 1962 from the Lenan of Kyrgyzstan as the type species. According to Andreeva (1987, p. 24), Narynella is distinguished from the similar Nisusia by a costellate external ornamentation lacking spines and the development of a ventral fold and a dorsal sulcus, i.e., a unisulcate commissure. The ventral valve of Narynella ferganensis is conical in lateral profile, whereas that of Nisusia sulcata Rowell \& Caruso, 1985 (a species tentatively assigned to Narynella by Andreeva 1987) is convex. As a result, two morphotypes distinguished by the shape of the ventral valve are also present within Narynella. Narynella is 
currently distinguished from Nisusia by the nature of the commissure only, which is rectimarginate or emarginated in Nisusia.

Remarks. - Popov \& Williams (2000) and Holmer et al. (2001) described, probably erroneously, Narynella as having a ventral sulcus and a dorsal fold, rather than a ventral fold and a dorsal sulcus.

There seems to be some confusion about the age and origin of the type material of Nisusia ferganensis, the type species of Narynella. In the protologue, Andreeva (1962, p. 89-90) described the material as originating from the Madygen area ("урочище Мадыген”) of the southern Fergana Basin, which is located in the Batken district of present-day Kyrgyzstan (see Geological setting above). The age of the material was referred to the "Lenan", a stratigraphical equivalent to the Botoman and Toyonian stages. In her introduction of the genus Narynella, Andreeva (1987, p. 34) listed the type material as from the Lenan Stage of the Fergana Basin, Uzbekistan [sic]. In their description of Narynella cf. ferganensis from Kazakhstan, Holmer et al. (2001, p. 150) referred to the type material as being of Amgan age and to originate from the "Fergana valley, Uzbekistan". The precise age of the type material remains uncertain because no specific information was provided by Andreeva $(1962,1987)$ nor details of the associated fauna. Based on the age of other occurrences of Narynella ferganensis, i.e., the Ptychagnostus atavus Biozone of the Malyi Karatau, Kazakhstan (Holmer et al. 2001), and the Sdzuyella-Aegunaspis Zone of the southern Fergana Basin, Kyrgyzstan (Aksarina 1975; data presented herein), an Amgan age appears to be more likely for the type material.

\section{Narynella cf. ferganensis (Andreeva, 1962)}

Figure 8A-J

1962 Nisusia ferganensis sp. nov.; Andreeva, pp. 89-90, fig. 2.

1975 Nisusia nasuta var. ramosa Nikitin, 1956. - Aksarina, pp. 97-98, pl. 5, figs 10-15.

? 2001 Narynella cf. ferganensis (Andreeva, 1962). - Holmer et al., pp. 152, 154, pl. 48, figs 1-7.

Type material. - From the Madygen area (урочище Мадыген), Fergana Basin, Kyrgyzstan.

Material. - Fifteen valves, of which eight are ventral (FG 596/XII/005c, FG 596/XII/006a, FG 596/XII/009b, FG 596/XII/010c, FG 596/XII/025a, FG 596/XII/028a, FG 596/XII/030a, FG 596/XII/032a), and seven are dorsal (FG 596/XII/013a, FG 596/XII/013b, FG 596/XII/020a,
FG 596/XII/020b, FG 596/XII/023a, FG 596/XII/026a, FG 596/XII/027a).

Description. - Shell markedly ventribiconvex, transversely subrectangular in outline, reaching its maximum width at about midlength; cardinal extremities obtuse. External shell surface costellate with most apical area typically smooth. Ventral valve conical, with straight lateral slopes and a straight to concave anterior slope; maximum height at pointed umbo, which is perforated by a relatively large foramen. Ventral interarea smooth, catacline, divided by strongly convex, long pseudodeltidium. Sharp flexures between propareas and pseudodeltidium accentuate pseudodeltidium and posterior margin. Delthyrium not clearly seen but probably low, rounded triangular, measuring less then one third of valve height. Dorsal valve convex, with straight to gently convex lateral slopes and an anterior slope that is initially convex but straightens out towards the anterior margin; maximum height at about one third of valve length from umbo. A shallow, broad median sulcus can only be seen in large specimens (Fig. 8H). Dorsal interarea broad, anacline. Internal characters of both valves not observed except for the costellate ornamentation that is also faintly visible on internal shell surfaces (Fig. 8A). Specimens measure 4.4 to $8.4 \mathrm{~mm}$ in length and 6.6 to $11.0 \mathrm{~mm}$ in width. Seemingly complete specimens (Fig. 8D, G) suggest a length-width ratio of about 0.75 .

Discussion. - Specimens described as Narynella cf. ferganensis by Holmer et al. (2001) from the Amgan (Ptychagnostus atavus Biozone) of the Malyi Karatau, Jambyl (earlier: Dzhambul) Province, south-east Kazakhstan, are questionably referred to $N$. ferganensis as ventral valves from this locality were described as moderately convex rather than conical.

Andreeva (1962) measured lengths and widths of $N$. ferganensis reaching 14 and $17 \mathrm{~mm}$, respectively. The specimens from Sauk Tanga are smaller suggesting that they result from juvenile individuals. This assumption is supported by the general absence of a fold and sulcus in the studied specimens except for the largest valve. This matches the ontogeny described for Narynella sulcata, in which a rectimarginate commissure was observed in juvenile and a unisulcate one in adult valves (Rowell \& Caruso 1985).

\section{Narynella? sp.}

Figure 9E-G

Material. - Two dorsal valves, FG 596/XII/024a and FG 596/XII/031a.

Description. - Both dorsal valves are strongly convex in 


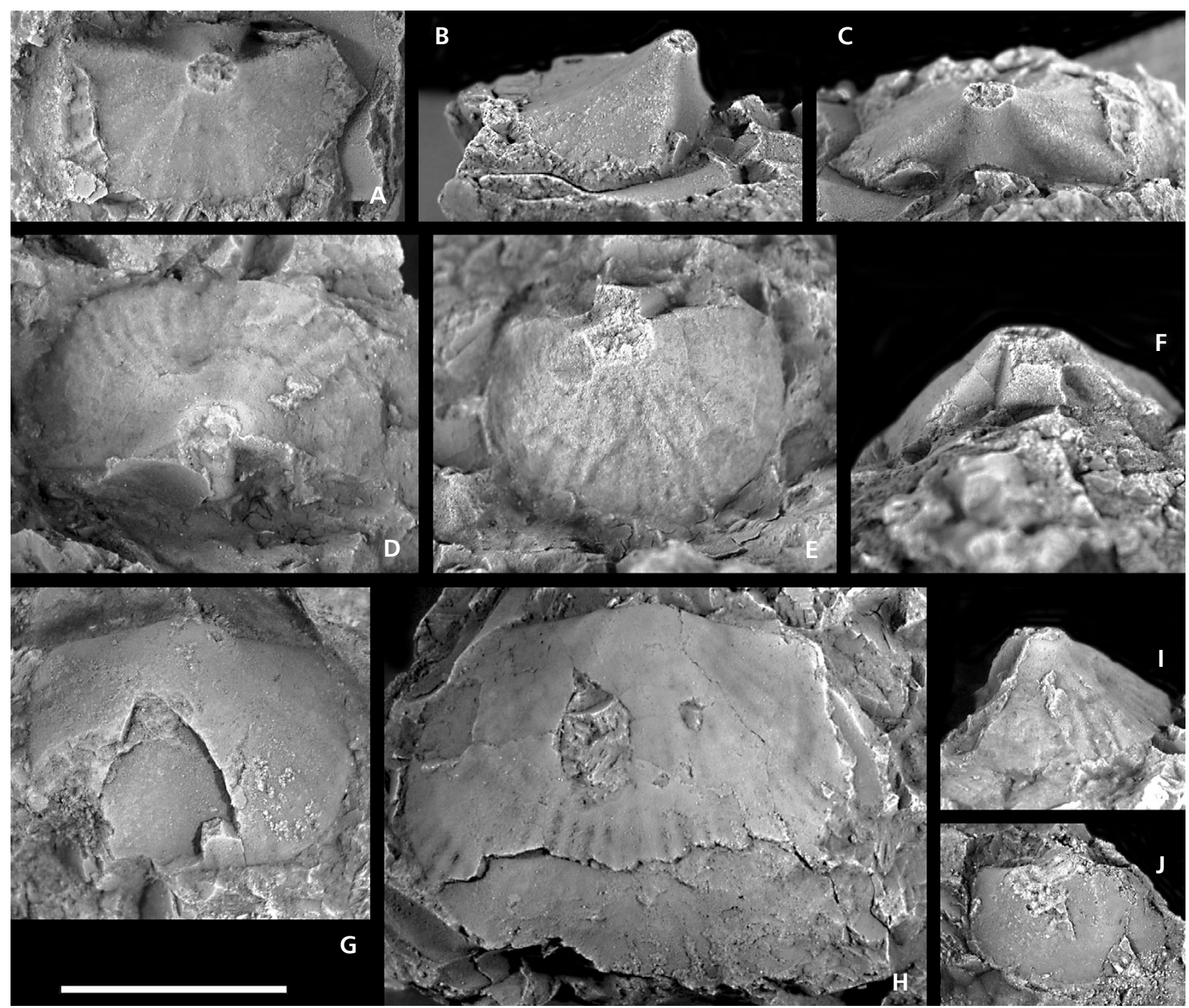

Figure 8. Narynella cf. ferganensis (Andreeva, 1962), Sauk Tanga locality. • A-C - internal mould of ventral valve FG 596/XII/025a; A - ventral view with remains of costellate shell to the left; B - lateral view showing concave anterior slope; $\mathrm{C}$ - posterior view with distinct pseudodeltidium. $\bullet \mathrm{D}, \mathrm{I}-\mathrm{ven}$ tral valve in ventral and lateral views, FG 596/XII/032a. • E, F - ventral valve in ventral and posterior views, FG 596/XII/025a. • G - relatively smooth dorsal valve, FG 596/XII/020a. • H - large costellate dorsal valve with shallow sinus, FG 596/XII/027a. • J - latex cast of interior of small ventral valve, FG 596/XII/009b. Scale bar $5 \mathrm{~mm}$.

lateral profile with the strongest convexity at the umbo; convexity decreases anteriorly. Lateral slopes are concave resulting in a prominent umbonal area and a more straightened appearance of the posterior margin of the valve in dorsal view (Fig. 9E). Smooth umbo overhangs a seemingly broad but short anacline interarea. Cardinal extremities obtuse. External shell surface costellate, except for umbonal area; individual costae and intercalated costellae strong, rounded in cross-section. Origin of costellae (by intercalation or branching) not determinable. A faint median depression at the anterior shell margin might indicate the development of a sulcus (Fig. 9F). A single, prominent growth lamella is developed close to the margin of one valve. The larger of the two valves (Fig. 9E-G) is $5.4 \mathrm{~mm}$ long and $7.2 \mathrm{~mm}$ wide, its maximum width at about midlength.

Discussion. - The described dorsal valves are similar to juvenile dorsal valves of Narynella cf. ferganensis with respect to size, proportions, and general outline as well as ornamentation of the shell exterior. The umbo, however, is more pronounced in Narynella? sp. resulting in a more strophic appearance of the valves. In addition, growth lamellae have not yet been noticed for Narynella, but are not uncommon for nisusiids (e.g., Bell 1941, Benedetto \& Foglia 2012). However, internal characters and the morphology of the interarea are needed for a confident placement under Narynella. 
Class Rhynchonellata Williams, Carlson, Brunton, Holmer \& Popov, 1996

Order Orthida Schuchert \& Cooper, 1932

Suborder Orthidina Schuchert \& Cooper, 1932

Superfamily Plectorthoidea Schuchert \& LeVene, 1929

Family Eoorthidae Walcott, 1908

\section{Genus Austrohedra Roberts \& Jell, 1990}

Discussion. - The genus Austrohedra was described by Roberts \& Jell (1990) from the Middle Cambrian (Ordian) Coonigan Formation of New South Wales and placed in the family Eoorthidae Walcott, which was followed by Williams \& Harper (2000b). The type species, A. mimica Roberts \& Jell, 1990, is currently the only recognised species of this genus, but the two valves described below might represent a new species of Austrohedra or a new, closely related taxon.

\section{Austrohedra? sp. nov.}

Figure 9A-C

Material. - Internal mould of a single ventral valve, FG 596/XII/019b, and one dorsal valve, FG 596/XII/009a.

Description. - Shell strophic, ventribiconvex, transversely rectangular to semicircular in outline with maximum width at hinge line or slightly anterior to it. Cardinal extremities not clearly visible, acute to rectangular or somewhat obtuse. No fold or sinus observed in either valve suggesting a rectimarginate commissure. External shell surface costellate with prominent, rounded costae and costellae of subequal thickness; number of costellae increases by intercalation. Ventral valve high, hemi-conical with greatest height at apex. Lateral slopes and anterior slope gently convex. Steep, procline to catacline interarea divided by wide, seemingly open, high delthyrium. Internally with low, short platform in the umbonal apex (muscle platform?); platform transversely rectangular in outline, broadens slightly anteriorly before it merges with the valve floor. Mould of ventral valve $7.5 \mathrm{~mm}$ wide, $3.8 \mathrm{~mm}$ long, and $2 \mathrm{~mm}$ high.

Dorsal valve convex, with straight lateral slopes and convex anterior slope; maximum height at about one-third of valve length from umbo. Umbo slightly overhangs short, anacline interarea featuring a low notothyrium. Internal features of dorsal valve not known. Valve is about $7.6 \mathrm{~mm}$ wide (reconstructed width based on the complete left half of the valve) and $4.4 \mathrm{~mm}$ long.

Discussion. - The observed characters of the two valves described above match best with the monotypic Australian genus Austrohedra Roberts \& Jell and its type species
A. minima. However, a few differences qualify this assignment. Shells of A. minima and Austrohedra? sp. nov. share the same outline and external ornamentation, are ventribiconvex, and have a rectimarginate commissure. Their ventral valves are hemiconical with a broad and steep, flat interarea divided by an open delthyrium, and their dorsal valves are convex with a broad, open notothyrium. Distinct differences between the two taxa exist in: 1) the inclination of the ventral interarea, which has been described as catacline to slightly apsacline in A. minima (Roberts \& Jell, 1990) rather than steeply procline to catacline as in Austrohedra? sp. nov.; and 2) the development of a broad and shallow dorsal sulcus in A. minima, which is not seen in Austrohedra? sp. nov. While such differences could be explained as intrageneric variation, observed discrepancies among internal characters are more significant. The apex of Austrohedra? sp. nov. bears a rectangular platform, which appears to be unknown from other Cambrian rhynchonelliform brachiopods. In contrast, the apex of $A u$ strohedra is characterised by an apically elevated pseudospondylium (Roberts \& Jell 1990). We interpret the platform observed in Austrohedra? sp. nov. to be formed of secondary shell, analogous to a pseudospondylium. The actual pseudospondylium and dental plates might be rudimentary and not preserved on the internal mould of Austrohedra? sp. nov. Potentially comparable platforms are present in various Furongian to Ordovician orthids such as the eoorthid genus Apheoorthis Ulrich \& Cooper, 1938 or the archaeorthid Archaeorthis Schuchert \& Cooper, 1931. There, the platform presents the anterior support of the pseudospondylium (e.g., Ulrich \& Cooper 1938, pl. 10, figs 5, 17 or pl. 13, figs 9-12).

Austrohedra? sp. nov. is also similar to the genus Arctohedra Cooper, 1936, a genus previously accommodated within the protorthids (Williams \& Harper 2000a), but now considered to be a basal clitambonitoid (Rubel 2007, Topper et al. 2013). The genera Austrohedra and Arctohedra are almost identical externally, except for the cardinal extremities, which are acute in Arctohedra rather than obtuse, and the ventral valve, which may be procline to catacline in Arctohedra (Cooper 1936, Roberts \& Jell 1990, Brock 1998), quite similar to that of Austrohedra? sp. nov. However, ventral valves of Arctohedra are characterised by a free spondylium growing from the inner ventral margins of the delthyrium (Cooper 1936, Roberts \& Jell 1990, Williams \& Harper 2000a). No such structure appears to be developed in Austrohedra? sp. nov. Nevertheless, the apical platform of the ventral valve from Sauk Tanga is reminiscent of configurations described from other basal clitambonitoids. Such genera include the early Ordovician Apomatella Schuchert \& Cooper, 1931 and the late Cambrian Roanella Brock \& Talent, 1999. Both genera show an apical shell thickening in their ventral valves that is reminiscent of the platform 


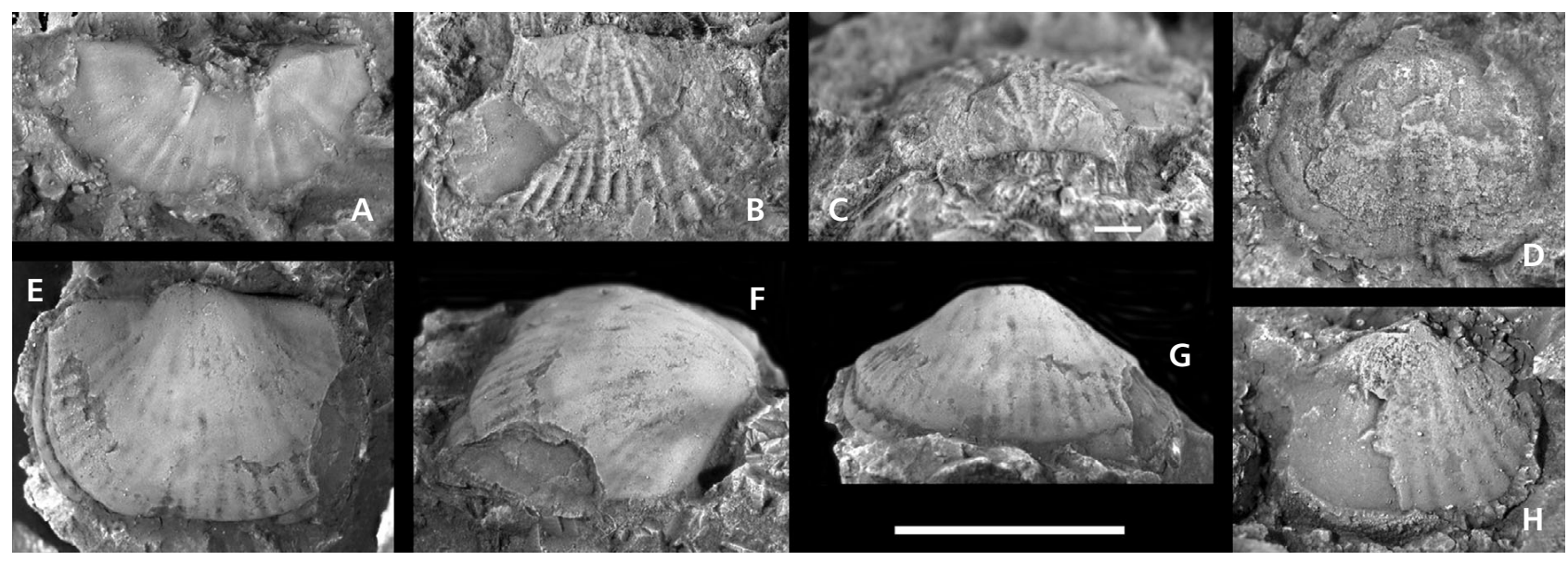

Figure 9. A-C - Austrohedra? sp. nov.; A - internal mould of procline ventral valve showing impression of apical rectangular platform, FG 596/XII/019b; B, C - dorsal valve in dorsal and posterior views, FG 596/XII/009a. $\bullet$ D - gen. and sp. undet. 1, corroded shell exterior of presumed ventral valve with shallow sulcus near anterior margin, FG 596/XII/007c. • E-G - Narynella? sp., dorsal valve with distinct growth lamella in dorsal, oblique lateral, and anterior view, FG 596/XII/024a. • H - gen. and sp. undet. 2, partly exfoliated exterior of presumed dorsal valve, FG 596/XII/012b. Scale bar 5 mm.

of Austrohedra? sp. nov. In Apomatella, this thickening is a short, anteriorly broadening ridge, which is the support of a rudimentary, short spondylium. Roanella lacks a spondylium but has a similar thickening, which defines the anterior border of its ventral apical muscle field (Brock \& Talent 1999, Topper et al. 2013). According to the cladistic analysis of Topper et al. (2013), Arctohedra, Roanella, and Apomatella all belong at the base of the clitambonitoid branch. Based on the similarities of Austrohedra? sp. nov. with these taxa and the observed variability in basal clitambonitoids, the two valves from Sauk Tanga may be interpreted to represent a taxon in a similar position. However, the lack of information concerning the dorsal interior of Austrohedra? sp. nov., in particular the configuration of the cardinalia, makes a clitambonitoid affinity conjectural. The same is true for the suggested eoorthid affinity. Nevertheless, an eoorthid affinity of Austrohedra? sp. nov. appears to be the most parsimonious interpretation at present.

Class, order, and family indet.

\section{Gen. and sp. indet. 1}

Figure 9D

Material. - One partly exfoliated ventral? valve, FG 596/XII/007c.

Description. - The single valve is subspherical to transversely ovaloid in outline, about $5.0 \mathrm{~mm}$ long and $6.3 \mathrm{~mm}$ wide with the maximum width slightly anterior to midlength. Poorly visible hinge line is either astrophic or extremely narrow. Valve is evenly convex in lateral and posterior view. An external ornamentation of seemingly fine costellae is only pre- served within a shallow sulcus at the anterior margin. Apex appears pronounced, suggesting a ventral valve.

Discussion. - See Discussion of Gen. and sp. indet. 2.

\section{Gen. and sp. indet. 2}

Figure $9 \mathrm{H}$

Material. - One partly exfoliated probable dorsal valve, FG 596/XII/012b.

Description. - The single valve is subspherical to subtriangular in outline, about $4.2 \mathrm{~mm}$ long and $5.8 \mathrm{~mm}$ wide with the maximum width at about $60 \%$ of length from posterior margin. Poorly visible hinge line is either astrophic or narrow. Valve is convex in lateral profile with the maximal convexity at the umbo; lateral and anterior slopes are straight and no signs of a sulcus or fold are visible. External ornamentation consist of strong rounded costae and costellae. Apex inconspicuous at convex posterior margin, suggesting a dorsal valve.

Discussion. - Narrowly strophic or astrophic, costellate shells with a potential uniplicate or rectimarginate commissure are not common among Cambrian rhynchonelliform brachiopods. Taxa superficially resembling gen. and sp. undet. 1 and 2 belong to the obolellate Family Naukatidae (e.g., Naukat Popov \& Tikhonov, 1990 or the poorly understood Swantonia Walcott, 1905) and the pentameride family Tetralobulidae (subfamily Syntrophopsinae). However, due to the lack of information on any internal characters and the poor state of preservation of both valves that might also comprise the observed shell outlines, we refrain from a systematic assignment of the two specimens. 
Incertae sedis

Order Tommotiida Missarzhevskiy, 1970

\section{Genus Tesella Missarzhevskiy \& Grigor’yeva, 1981}

Type species (by original designation). - Tesella deplanata Missarzhevskiy \& Grigor'yeva, 1981, from the early part of the Amgan Stage of Mt. Sladkiye Koren'ya, Kuznetsk Alatau Range, Russia.

Discussion. - Missarzhevskiy \& Grigor'yeva (1981) described 5 tommotiid sclerite-types from the Amgan Stage of Mt. Sladkiye Koren'ya, which they attributed to new species of Sonella Missarzhevskiy \& Grigor'yeva, 1981 and Tesella. No discussion of the reconstruction of these sclerite-types into a scleritome was given. Yuan \& Zhang (1983) did not accept Sonella and Tesella in their description of early (Tommotian-Atdabanian) tommotiids from south-west China, although Qian (1989) did (with Tesella given as "Tessella"). Schopf \& Klein (1992) synonymised Sonella with Tesella.

\section{Tesella sp.}

Figure 3E, F

Material. - The illustrated fragmentary specimen, FG 596/XII/016b, and several other minute fragments.

Discussion. - The figured fragment shows traces of the transverse septa on the inner wall and behind this, the coarse, corded, ornament of the outer surface (Fig. 3F). The overall shape of the sclerite cannot be accurately ascertained; it most closely resembles $T$. deplanata, the holotype (Missarzhevskiy \& Grigor'yeva 1981, pl. XI, figs 5, 6), but this has coarser, more widely spaced cords on the outer surface. A similar association of sclerites to that described by Missarzhevskiy \& Grigor'yeva (1981) from Mt. Sladkiye Koren'ya occurs in the Henson Gletscher Formation of North Greenland (C.B. Skovsted and J.S. Peel, unpublished observations) in strata yielding Ovatoryctocara granulata Chernysheva, 1961 and thus of similar age to the Russian occurrence (Geyer \& Peel 2011).

Incertae sedis

Order Hyolithelminthida Fischer, 1962

Family Hyolithellidae Walcott, 1886

\section{Genus Hyolithellus Billings, 1871}

Type species (by original designation). - Hyolithus micans Billings, 1871, from the Bonnia-Olenellus Zone, Dyeran Stage; Troy, New York State, U.S.A.

\section{Hyolithellus sp. \\ Figure 3G}

Material. - Several small fragments and fragmentary specimen, FG 596/XII/004b.

Discussion. - The largest of several small fragments assigned to Hyolithellus sp. is illustrated here. Maximum preserved length is $5 \mathrm{~mm}$ with a diameter of $1.5 \mathrm{~mm}$. The shell is largely exfoliated, showing the imbrication of growth lamellae, the succession of which forms the fine transverse ornamentation on the tube exterior. Most described Hyolithellus are considerably narrower than the current specimen although Skovsted \& Peel (2011) figured even larger specimens, with unusually thick walls, that occur in situ in the lower Cambrian of North Greenland.

Incertae sedis

Class Palaeoscolecida Conway Morris \& Robison, 1986 Family Palaeoscolecidae Whittard, 1953

\section{Genus Hadimopanella Gedik, 1977}

Type species (by original designation). - Hadimopanella oezgueli Gedik, 1977, from the Middle Cambrian (assigned to the Upper Cambrian in the protologue) of the Central Taurus, north of Bađbațý, Konya Province, Turkey.

Discussion. - Hadimopanella Gedik is a form genus for button-shaped palaeoscolecid sclerites that are commonly found in Cambrian sediments. They are known since the lower Cambrian (upper Atdabanian, Cambrian Stage 3; Bengtson 1977) and might reach into the Middle Ordovician (Van den Boogaard 1989). Intraspecific variability of palaeoscolecid sclerites can be quite extensive as it has been observed in sclerite rich sediments (e.g., Van den Boogaard 1983, Peel \& Larsen 1984, Streng \& Ebbestad 2007) or in specimens with partly preserved articulated scleritomes (e.g., Ivantsov \& Wrona 2004). Thus, it is important to have a sufficient number of specimens when describing disarticulated material to critically assess the potential morphological variability of a taxon. Studies of palaeoscolecid scleritomes have, however, also revealed that the same morphotype of a sclerite may occur in apparently different species and genera (e.g., Ivantsov \& Zhuravlev 2005, Topper et al. 2010).

Sclerites of Hadimopanella are button or discus-shaped with one side of the discus being smooth and generally gently convex (the so called "proximal", "lower", or "smooth surface"), whereas the other side ("distal" or "upper surface") is elevated centrally and ornamented by nodes of variable sizes and numbers. The distal surface can be subdivided into a marginal area without nodes (the so 
called "brim") and a central area bearing the nodes (also termed the "crown"). The brim is typically ornamented by fine radial grooves and clearly delineated from the crown by a suture (basal suture). The crown itself can be further subdivided in some taxa into a marginal, typically smooth and node-free zone (termed the "girdle"), and the crown sensu stricto, i.e., the innermost area bearing the nodes (also called "nodular face") (for terminology see, e.g., Bengtson 1977 and Wrona 1982).

\section{Hadimopanella oezgueli Gedik, 1977 Figure 10A-F}

1977 Hadimopanella oezgueli n. sp.; Gedik, pp. 46-47, pl. 5, figs 1-5.

1983 Hadimopanella oezgueli Gedik, 1977. - Van den Boogaard, pp. 337, 339, 340, figs 3-5.

1988 Hadimopanella oezgueli Gedik, 1977. - Märss, pp. 14-15, pl. 1, figs $1-8$.

n 2001 Hadimopanella oezgueli Gedik, 1977. - Wrona \& Hamdi, pp. 104-105, pl. 1, figs 1-5, pl. 2, figs 1-8, pl. 3, figs 1-6.

? 2003 Hadimopanella sp. - Elicki et al., pl. 5, figs 12-23.

2011 Hadimopanella knappologica (Bengtson, 1977). Kouchinsky et al., pp. 43-44, fig. 32.

[selective synonymy that summarises the regional and stratigraphic distribution of the taxon]

Type material. - Middle Cambrian of the central Taurids, Konya Province, Turkey.

Material. - Five individual sclerites, FG 596/XII/034a-e.

Description. - Individual sclerites are circular to somewhat ovaloid in outline, measuring 147 to $187 \mu \mathrm{m}$ in maximum diameter $(n=5)$. An about $18 \mu \mathrm{m}$ broad brim is preserved in four of the specimens, ornamented by fine radiating grooves; brim width appears to be constant und independent of sclerite size. Brim concave, straight or slightly convex in lateral profile, typically somewhat less inclined than the girdle. One specimen shows a brim that is additionally ornamented by adjoining circular shallow depressions, with the diameter of the depressions matching the brim width (Fig. 10A). Girdle variably developed among observed specimens; either fully expressed, i.e., surrounding central noded area (Fig. 10C), or partially developed only, i.e., partly surrounding center (Fig. 10A), or reduced to one sector of crown (Fig. 10B). Nodes in centre of crown measure about 13 to $28 \mu \mathrm{m}$ in diameter and are arranged in two concentric to slightly eccentric rings around a centre. In the centre of the ring, which does not have to be the centre of the sclerite, a single node may be developed (Fig. 10A, C). Observed number of nodes in crown



Figure 10. Hadimopanella oezgueli Gedik, 1977, Sauk Tanga locality. - A, D, F-specimen with 19 nodes $(19=11+7+1$; see text for further explanation) and five accessory nodes on girdle, in distal (A), lateral (D), and close-up view (F), FG 596/XII/034a. • B - specimen with 15 nodes $(15=10+5+0)$, FG $596 / \mathrm{XII} / 034 \mathrm{~b}$; note that the girdle is only developed in the upper left sector. $\bullet \mathrm{C}, \mathrm{E}-$ specimen with 22 nodes $(22=14+7+1)$ in distal and lateral view, FG 596/XII/034c. Scale bar $50 \mu \mathrm{m}$, except F $(25 \mu \mathrm{m})$.

centre varies between 15 and $22(n=4)$, with ten to 14 nodes in outer ring, and five or seven in the inner ring. Two specimens have a single node in the middle of the second ring (Fig. 10A, C). One specimen bears five small, accessory nodes on the girdle (Fig. 10F) measuring 7.5 to $9.5 \mu \mathrm{m}$ in basal diameter.

Discussion. - The arrangement of nodes in concentric rings, with the nodes being of similar sizes, is herein considered to be the characteristic feature of Hadimopanella oezgueli. Published data on the species shows that nodes can be arranged in three iterations, of which only one or all three can be expressed. Iteration one would be the presence of only one ring of nodes, iteration two is characterised by the presence of one ring of nodes with another ring in its centre. This second "ring" might also comprise only one or two nodes and can be of somewhat irregular shape. The third iteration defines the presence of nodes central to the second ring (see also Van den Boogaard 1983). Only a single node for the third iteration has been reported or depicted. Thus, nodes of $H$. oezgueli can be expressed in the formula 
$\mathrm{n}=\mathrm{i} 1+\mathrm{i} 2+\mathrm{i} 3$, with $\mathrm{n}$ being the total number of crown nodes and i1 to i3, the number of nodes in each iteration with i1 being the outermost. According to literature data on H. oezgueli (see Synonymy), the variation ranges from 5 or 4 nodes $(5=5+0+0$, Van den Boogaard 1983, fig. 3f; $4=4+0+0$, Märss 1988, pl. 1 , fig. 1$)$ over 8 nodes $(8=7+$ $1+0$; holotype of Gedik 1977, pl. 5, fig. 1) to specimens with two fully developed iterations (see e.g., Fig. 10B, $15=10+5+0$; Märss 1988, pl. 1, figs 5-8; Kouchinsky et al. 2011, fig. 32), to three expressed iterations with up to 22 nodes (Fig. 10C, $22=14+7+1$; Van den Boogaard 1983, fig. 3a). The presence of up to 30 nodes has been reported (Van den Boogaard 1983); their arrangement, however, has not been depicted or described in detail. Accessory nodes on the girdle might increase the total number of nodes (Fig. 10F), but have here not been considered within the formula.

The specimens from Sauk Tanga are almost identical to specimens of $H$. oezgueli described from the upper Lancara Formation of Spain (Van den Boogaard 1983) with respect to size, the arrangement and number of nodes, and general sclerite topology. Furthermore, they are of similar age, with the Spanish specimens being slightly younger (Badulesia Biozone, lower Caesaraugustian/lower Drumian). Specimens from Kyrgyzstan (southeastern Fergana Basin) previously reported by Märss (1988) are somewhat smaller and bear a lower number of nodes. Wrona \& Hamdi (2001) described a rich association of isolated palaeoscolecid sclerites from a Furongian member of the Mila Group of Iran as H. oezgueli. These sclerites are, as also stated by Wrona \& Hamdi (2001), on average smaller and have a lower number of nodes than the Turkish, Spanish, or Kyrgyz specimens. In addition, the individual nodes appear to be more pointed. We consider the Iranian sclerites to fall outside the morphological variability of $H$. oezgueli. Specimens from the Amgan of the Siberian Platform described by Kouchinsky et al. (2011) as H. knappologica (Bengtson, 1977) show a distinct brim, a broad girdle, and an arrangement of the crown nodes in two iteration. The combination of these characters as well as their age suggest an affiliation with $H$. oezgueli rather than H. knappologica.

Palaeoscolecid sclerites from the Middle Cambrian Campo Pisano Formation of Sardinia have been described as Hadimopanella cf. oezgueli (Cherchi \& Schroeder, 1985) and Hadimopanella sp. (e.g., Elicki et al. 2003), respectively. These sclerites resemble $H$. oezgueli in size and general morphology, but their nodular faces are too poorly preserved to describe their morphological variability. As defined herein, H. oezgueli occurs in the Middle Cambrian Stages 5 and 6 and is known from Turkey, Spain, Kyrgyzstan, Siberia, and possibly Sardinia.

\section{Acknowledgements}

Fieldwork for this study was conducted by S. Voigt, J. Fischer and M. Preuße with financial support of the Deutsche Forschungsgemeinschaft (grants VO 1466/1-1, VO 1466/1-2, and SCHN 408/14-1). The contribution of G. Geyer has been supported by a research grant of the Deutsche Forschungsgemeinschaft (grant GE 549/21-1). In addition, financial support from the Swedish Research Council (Vetenskapsrådet) through grants to J.S. Peel and M. Streng is gratefully acknowledged. We are further indebted to O. Elicki (Freiberg) and J.S. Hollingsworth (Grand Junction, CO) for very careful reviews and constructive suggestions.

\section{References}

AKSARINA, N.A. 1975. Brakhiopody [Brachiopods], 91-100. In Repina, L.N., Yaskovich, B.V., Aksarina, N.A., Petrunina, Z.E., Ponilenko, I.A., Rubanov, D.A., Bolgova, G.V., GoliKov, A.N., Hajrullina, T.I. \& Posochova, M.M. Stratigrafiya $i$ fauna nizhnego paleozoya severnykh predgoriy Turkestanskogo i Alayskogo khrebtov (yuzhnyy Tyan'-Shan') [Stratigraphy and fauna of the Lower Paleozoic of the northern submontane belt of Turkestan and Alai Ridges (southern Tyan-Shan)]. Akademiya nauk SSSR, Sibirskoe otdelenie, Trudy Instituta geologii i geofiziki 278.

ANDREEVA, O.N. 1962. Nekotorye kembriyskie brakhiopody Sibiri i Sredney Asii [Some Cambrian brachiopods of Siberia and Central Asia]. Paleontologicheskiy Zhurnal 1962(2), 87-96.

ANDREEVA, O.N. 1987. Kembriyskie zamkovye brakhiopody [Cambrian articulate brachiopods]. Paleontologicheskiy Zhurnal 1987(4), 31-40.

Bazhenov, M.L. 1993. Cretaceous paleomagnetism of the Fergana Basin and adjacent ranges, central Asia: tectonic implications. Tectonophysics 221(2), 251-267.

DOI 10.1016/0040-1951(93)90335-H

BeLL, W.C. 1941. Cambrian Brachiopoda from Montana. Journal of Paleontology 15(3), 193-255.

Benedetto, J.L. \& Foglia, R.D. 2012. Lower and Middle Cambrian rhynchonelliform brachiopods from the Precordillera Terrane of Argentina. Journal of Paleontology 86(2), 273-281. DOI 10.1666/10-115.1

Bengtson, S. 1977. Early Cambrian button-shaped phosphatic microfossils from the Siberian Platform. Palaeontology 20(4), 751-762.

BEREZANSKII, A.V. 1999. Geological structure and natural resources of the Sulyukta ore district (Tokhta-Buz area). Report on the results of geological mapping, geological reconnaissance, and general prospection at the scale of 1:50,000, conducted by the Tokhta-Boz party in 1993-1998. 450 pp. Unpublished report, Geological Survey of Southern Kyrgyzstan, Osh.

Berner, U., Scheeder, G., Kus, J., Voigt, S. \& Schneider, J.W. 2009. Organic geochemical characterization of terrestrial source rocks of the Triassic Madygen Formation (Southern Tien Shan, Kyrgyzstan). Oil and Gas 35, 135-139. 
BiLLings, E. 1861. On some new or little-known species of Lower Silurian Fossils from the Potsdam Group (Primordial zone). Geological Survey of Canada, Separate Report 464, 1-18.

Billings, E. 1871. On some new species of Palaeozoic fossils. Canadian Naturalist 6, 213-233, 240.

Brock, G.A. 1998. Middle Cambrian articulate brachiopods from the southern New England Fold Belt, northeastern N.S.W., Australia. Journal of Paleontology 72(4), 604-619.

Brock, G.A. \& TAlent, J.A. 1999. Roanella, a new ?billingselloid brachiopod from the Late Cambrian Dolodrook limestones, east-central Victoria. Proceedings of the Royal Society of Victoria 111, 107-120.

Burtman, V.S. 1997. Kyrgyz Republic, 483-492. In Moores, E.M. \& FAIRBRIDGE, R.W. (eds) Encyclopedia of European and Asian Regional Geology. Chapman \& Hall, London.

Burtman, V.S. 2008. Nappes of the Southern Tien Shan. Russian Journal of Earth Sciences 10, 1-35.

DOI 10.2205/2007ES000223

Cherchi, A. \& Schroeder, R. 1985. Middle Cambrian Foraminifera and other microfossils from SW Sardinia. Bollettino della Società Paleontologica Italiana 23, 149-160.

Chernysheva, N.E. 1950. Novye srednekembriyskie trilobity vostochnoy Sibiri [New Middle Cambrian Trilobites of Eastern Siberia]. Trudy Vsesoyuznogo nauchno-issledovatel'skogo geologicheskogo instituta (VSEGEI) 1, 67-78.

Chernysheva, N.E. 1961. Stratigrafiya kembriya Aldanskoy anteklizy i paleontologicheskoe obosnovanie vydeleniya amginskogo yarusa [Stratigraphy of the Cambrian of the Aldan Anteclise and the palaeontological basis of the distinction of the Amgan stage]. Stratigrafiya i fauna kembriyskikh otlozheniy Sibirskoy platformy, ch. 1. Trudy Vsesoyuznogo nauchno-issledovatel'skogo geologicheskogo instituta (VSEGEI), novaya serya $49,347 \mathrm{pp}$.

Chernysheva, N.E. (ed.) 1971. Amginskiy yarus Altae-Sayanskoy oblasti. Trudy Sibirskogo nauchno-issledovatel'skogo instituta geologii, geofiziki i mineralnogo syr'ya (SNIIGGiMS), Serya paleontologiya i stratigrafiya III, $267 \mathrm{pp}$.

Conway Morris, S. \& Robison, R.A. 1986. Middle Cambrian priapulids and other soft-bodied fossils from Utah and Spain. The University of Kansas Paleontological Contributions 117, $1-22$.

Cooper, G.A. 1936. New Cambrian brachiopods from Alaska. Journal of Paleontology 10(3), 210-214.

CUVIER, G. 1797. Tableau élémentaire de l'histoire naturelle des animaux. 710 pp. Baudoin, Paris.

Dames, W. 1883. Kambrische Trilobiten von Liao-tung, 3-33. In Richthofen, F.F. China. Ergebnisse eigener Reisen und darauf gegründete Studien. Band 4, Paläontologie. 792 pp. Dietrich Reimer, Berlin.

Dobruskina, I.A. 1995. Keuper (Triassic) flora from Middle Asia (Madygen, Southern Fergana). New Mexico Museum of Natural History and Science Bulletin 5, 1-49.

DuMERIL, A.M.C. 1806. Zoologie analytique, ou méthode naturelle de classification des animaux, rendue plus facile à l'aide de tableaux synoptiques. xxiv + 344 pp. Allais, Paris.

EgorovA, L.I. 1962. O nakhodke novogo vida roda Glabrella $\mathrm{v}$ nizhnem kembrii [Concerning a discovery of a new species of Glabrella in the Lower Cambrian]. Materialy po paleontologii i stratigrafli zapadnoy Sibiri. Trudy Sibirskogo nauchno-issledovatel'skogo instituta geologii, geofiziki i mineralnogo syr'ya (SNIIGGiMS) 23, 158-159.

Elicki, O. Hamann, Y. \& Münzberger, P. 2003. Biofazies, Paläoökologie und Ablagerungsmodell des Finalstadiums einer kambrischen Karbonatplattform-Entwicklung: die Fauna der Campo Pisano Formation SW-Sardiniens. Freiberger Forschungshefte C 499, 1-33.

Engelbretsen, M.E. 1993. A Middle Cambrian possible cnidarian from the Murrawong Creek Formation, NE New South Wales. Memoir of the Association of Australasian Palaeontologists 15, 51-56.

Fischer, J., Voigt, S., Schneider, J.W., Buchwitz, M. \& Voigt, S. 2011. A selachian freshwater fauna from the Triassic of Kyrgyzstan and its implication for Mesozoic shark nurseries. Journal of Vertebrate Paleontology 31(5), 937-953. DOI 10.1080/02724634.2011.601729

FISHER, D.W. 1962. Other small conoidal shells, W98-W143. In Moore, R.C. (ed.) Treatise on Invertebrate Paleontology, Miscellanea. Geological Society of America and University of Kansas, Lawrence.

GEDIK, İ. 1977. Orta Toroslar'da konodont biyostratigrafisi [Conodont stratigraphy in the Middle Taurus]. Bulletin of the Geological Society of Turkey 20, 35-48.

GEYER, G. 1986. Mittelkambrische Mollusken aus Marokko und Spanien. Senckenbergiana lethaea 67(1/4), 55-118.

GEYER, G. 1990. Die marokkanischen Ellipsocephalidae (Trilobita: Redlichiida). Beringeria 3, 1-363.

GEYER, G. 1994. Middle Cambrian mollusks from Idaho and early conchiferan evolution, 69-86. In LANDING, E. (ed.) Studies in Stratigraphy and Paleontology in Honor of Donald W. Fisher. N. Y. State Museum Bulletin 481.

Geyer, G. \& PeEl, J.S. 2011. The Henson Gletscher Formation, North Greenland, and its bearing on the global Cambrian Series 2-Series 3 boundary. Bulletin of Geosciences 86(3), 465-543. DOI 10.3140/bull.geosci.1252

Ghobadi Pour, M. \& Popov, L.E. 2009. Silicified Middle Cambrian trilobites from Kyrgyztan. Palaeontology 52(5), 1039-1056. DOI 10.1111/j.1475-4983.2009.00906.x

Gubanov, A.P., Kouchinsky, A.V., Peel, J.S. \& Bengtson, S. 2004. Middle Cambrian molluscan fauna of Australian aspect from northern Siberia. Alcheringa 28(1), 1-20. DOI 10.1080/03115510408619272

Gubanov, A.P. \& PeEL, J.S. 2001. Latest helcionelloid molluscs from the Lower Ordovician of Kazakhstan. Palaeontology 44(4), 681-694. DOI 10.1111/1475-4983.00198

Holmer, L.E., Popov, L.E., Koneva, S.P. \& Bassett, M.G. 2001. Cambrian-early Ordovician brachiopods from Malyi Karatau, the western Balkhash region, and Tien Shan, Central Asia. Special Papers in Palaeontology 65, 1-180.

Ivantsov, A.Y. \& WronA, R. 2004. Articulated palaeoscolecid sclerite arrays from the Lower Cambrian of eastern Siberia. Acta Geologica Polonica 54(1), 1-22.

Ivantsov, A.Y. \& Zhuravlev, A.Y. 2005. Golovokhobotnye [Cephalorhynchs], 61-72. In PonomarenKo, A.G. (ed.) Unikalniye Sinskiye mestonakhozhdeniya rannekembriyskikh 
organizmov (Sibirskaya platforma) [Unique Sinsk localities of Early Cambrian organisms (Siberian Platform)]. Trudy Paleontologicheskogo instituta 284.

Jell, P.A. \& AdRAIN, J.M. 2002. Available generic names for trilobites. Memoirs of the Queensland Museum 48(2), 331-553.

Jell, J.S. \& Jell, P.A. 1976. Early Middle Cambrian corals from western New South Wales. Alcheringa 1(2), 181-195. DOI 10.1080/03115517608619070

KhAYRULLINA, T.N. 1973. Biostratigrafiya i trilobity mayskogo yarus srednego kembriya Turkestanskogo khrebta [Biostratigraphy and trilobites of the Middle Cambrian Mayan Stage from the Turkestan Range]. 112 pp. Central Asiatic Institute of Geology and Mineral Resources, FAN Publishing House, Tashkent.

Kobayashi, T. 1935. The Cambro-Ordovician formations and faunas of South Chosen. Paleontology. Part III. Cambrian faunas of South Chosen with a special study on the Cambrian trilobite genera and families. Journal of the Faculty of Sciences, Imperial University of Tokyo, Section II, 4(2), 49-344.

Kobayashi, T. 1944. The Cambrian formation in the middle Yangtze Valley and some trilobites contained therein. Japanese Journal of Geology and Geography 19, 89-105.

Kouchinsky, A., Bengtson, S., Clausen, S., Gubanov, A., MalinKy, J.M. \& Peel, J.S. 2011. A Middle Cambrian fauna of skeletal fossils from the Kuonamka Formation, northern Siberia. Alcheringa 35(1), 123-189. DOI 10.1080/03115518.2010.496529

Kunn, O. 1949. Lehrbuch der Paläozoologie. v + 326 pp. E. Schweizerbart, Stuttgart.

LAZARENKO, N.P. 1954. O nekotorykh srednekembriyskikh trilobitakh Sibiri. Vestnik Leningradskogo gosudarstvennogo universiteta, seriya biologiya, geografiya i geologiya 4, 154-164.

Lermontova, E.V. 1940. VI Tip - Arthropoda, 112-157. In Vologdin, A. (ed.) Atlas rukovodyashchikh form iskopaemykh faun SSSR. 1. Kembriy. Gosgeoltekhizdat, Moscow \& Leningrad.

LeRmontova, E.V. 1951. Srednekembriyskie trilobity i gastropody Shody-Mira (yuzhnaya okraina Ferganskoy kotloviny) [Middle Cambrian trilobites and gastropods of Shody-Mir]. Trudy Vsesoyuznogo nauchno-issledovatel'skogo geologicheskogo instituta (VSEGEI), $37 \mathrm{pp}$.

MÄrss, T. 1988. Early Palaeozoic hadimopanellids of Estonia and Kirgizia (USSR). Proceedings of the Academy of Sciences of the Estonian SSR, Geology 37(1), 10-17.

Matthew, G.F. 1887. Illustrations of the fauna of the St. John Group. 4. Part 1. Description of a new species of Paradoxides (Paradoxides regina). Part 2. The smaller trilobites with eyes (Ptychopariidae and Ellipsocephalidae). Transactions of the Royal Society of Canada 5(4), 115-166.

MeEK, F.B. 1877. Description of fossils collected by the U.S. Geological Survey under charge of Cl. King. United States Geological Explorations of the Fortieth Parallel. Paleontology 4(1), 1-197.

MissarzheVskiy, V.V. 1970. Novoye rodovoye nazvaniye Tommotia Missarzhevsky, nom. nov. [New generic name Tom- motia Missarzhevskiy, nom. nov.). Paleontologicheskiy Zhurnal 1970(4), 100.

MissarzheVsKiy, V.V. \& GRIGOR'YeVA, N.V. [MissarzheVsKy \& Grigorieva] 1981. New representatives of the Order Tommotiida. Paleontological Journal 1981(4), 96-103. [in Russian as Novyye predstavitelli otryada Tommotiida. Paleontologicheskiy Zhurnal 1981(4), 91-97.]

Moisan, P., Voigt, S., Pott, C., Buchwitz, M., Schneider, J.W. \& Kerp, H. 2011. Cycadalean and bennettitalean foliage from the Triassic Madygen Lagerstätte (SW Kyrgyzstan, Central Asia). Review of Palaeobotany and Palynology 164(1-2), 93-108. DOI 10.1016/j.revpalbo.2010.11.008

Nikitin, I.F. 1956. Brakhiopody kembriya i ordovika Tsentral'nogo Kazakhstana [Cambrian and Ordovician brachiopods from Central Kazakhstan]. 143 pp. Izdatel'stvo Akademiy nauk KazSSR, Alma-Ata.

Palmer, A.R. \& Gatehouse, C.G. 1972. Early and Middle Cambrian trilobites from Antarctica. United States Geological Survey, Professional Paper 456D, 1-37.

Park, T.-Y., Woo, J., Lee, D.-J., Lee, D.-C., Lee, S.-B., Han, Z., Chough, S.K. \& Chol, D.K. 2011. A stem-group cnidarian described from the mid-Cambrian of China and its significance for cnidarian evolution. Nature Communications 2, 442. DOI 10.1038/ncomms1457.

Peel, J.S. 1988. Molluscs of the Holmdal Formation (late Middle Cambrian), central North Greenland. Meddelelser om Grønland, Geoscience 20, 145-168.

PeEL, J.S. 1991. Functional morphology of the Class Helcionelloida nov., and the early evolution of the Mollusca, 157-177. In Simonetta, A.M. \& Conway Morris, S. (ed.) The early evolution of Metazoa and the significance of problematic taxa. Cambridge University Press, Cambridge.

Peel, J.S. 2011. The coral Cothonion from the lower Cambrian of North Greenland. Alcheringa 35(3), 405-411. DOI 10.1080/03115518.2011.521438

Peel, J.S. \& Larsen, N.H. 1984. Hadimopanella apicata from the Lower Cambrian of western North Greenland. Rapport Grønlands Geologiske Undersøgelse 121, 89-96.

Popov, L.E. \& TikHONOv, Y.A. 1990. Rannekembriyskiye brakhiopody iz Yuzhnoy Kirgizii [Early Cambrian brachiopods from southern Kirgizia]. Paleontologicheskiy Zhurnal 1990(3), 33-46.

Popov, L.E. \& Williams, A. 2000. Kutorginata, 208-215. In WILLiAms, A. et al. Treatise on Invertebrate Paleontology. Part. H, Brachiopoda, Revised, vol. 2. Geological Society of America \& University of Kansas, Boulder \& Lawrence.

Preube, M. 2011. Geologische Kartierung der Region Madygen, Abschnitt Sauk Tanga (Turkestanisches Gebirge, SW-Kirgisistan, Zentralasien) im Maßstab 1:5.000. 132 pp. Unpublished Diploma Mapping Thesis, TU Bergakademie Freiberg.

QIAN, Y. 1989. Early Cambrian small shelly fossils of China with special reference to the Precambrian-Cambrian boundary. Stratigraphy and palaeontology of systemic boundaries in China. Precambrian-Cambrian boundary 2. 341 pp. Nanjing University Publishing House, Nanjing.

RAYMOND, P.E. 1913. Some changes in the names of genera of trilobites. The Ottawa Naturalist 26, 137-142. 
RePINA, L.N. 1960. Opisanie trilobitov, 152-253. In Khalfin, L.L. (ed.) Biostratigrafiya paleozoya Sayano-Altayskoy gornoy oblasti. Tom 1, Nizhniy paleozoy [Biostratigraphy of the Palaeozoic of the Sayan-Altay mountain region. Volume 1, Lower Paleozoic]. Trudy Sibirskogo nauchno-issledovatel'skogo instituta geologii, geofiziki i mineralnogo syr'ya (SNIIGGiMS) 19.

Repina, L.N., Petrunina, Z.E. \& Khayrullina, T.I. 1975. Trilobity [Trilobites], 100-248. In RePINA, L.N., YASKovich, B.V., Aksarina, N.A., Petrunina, Z.E., Ponilenko, I.A., Rubanov, D.A., Bolgova, G.V., Golikov, A.N., Hajrullina, T.I. \& PosochovA, M.M. Stratigrafiya $i$ fauna nizhnego paleozoya severnykh predgoriy Turkestanskogo i Alayskogo khrebtov (yuzhnyy Tyan'-Shan') [Stratigraphy and fauna of the Lower Paleozoic of the northern submontane belt of Turkestan and Alai Ridges (southern Tyan-Shan)]. Akademiya nauk SSSR, Sibirskoe otdelenie, Trudy Instituta geologii i geofiziki 278.

Resser, C.E. 1939. The Ptarmigania strata of the northern Wasatch Mountains. Smithsonian Miscellaneous Collections 98(24), 1-72.

Roberts, J. \& Jell, P.A. 1990. Early Middle Cambrian (Ordian) brachiopods of the Coonigan Formation, western New South Wales. Alcheringa 14(4), 257-309.

DOI 10.1080/03115519008619059

Rowell, A.J. \& CAruso, N.E. 1985. The evolutionary significance of Nisusia sulcata, an early articulate brachiopod. Journal of Paleontology 59(5), 1227-1242.

Rubel, M. 2007. Clitambonitidina, 2680-2681. In Williams, A. et al. Treatise on Invertebrate Paleontology. Part H, Brachiopoda, Revised, vol. 6. Geological Society of America \& University of Kansas, Boulder \& Lawrence.

Schlotheim, E.F. von 1823. Nachträge zur Petrefactenkunde. Zweyte Abtheilung. 114 pp. Beckersche Buchhandlung, Gotha.

Schoch, R., Voigt, S. \& Buchwitz, M. 2010. A chroniosuchid from the Triassic of Kyrgyzstan and analysis of chroniosuchian relationships. Zoological Journal of the Linnean Society 160, 515-530.

DOI 10.1111/j.1096-3642.2009.00613.x

Schopf, J.W. \& KLeIN, C. (eds) 1992. The Proterozoic Biosphere. A Multidisciplinary Study. 1348 pp. Cambridge University Press, Cambridge, New York, Port Chester, Melbourne \& Sydney.

SChUChert, C. \& CoOper, G.A. 1931. Synopsis of the brachiopod genera of the suborders Orthoidea and Pentameroidea, with notes on the Telotremata. American Journal of Science, Series 5(22), 241-251. DOI 10.2475/ajs.s5-22.129.241

Schuchert, C. \& CoOper, G.A. 1932. Brachiopod genera of the suborders Orthoidea and Pentameroidea. Memoirs of the Peabody Museum of Natural History 4(1), xii +270 pp.

Schuchert, C. \& LeVene, C.M. 1929. Brachiopoda (generum et genotyporum index et bibliographia). In PoMPECKJ, J.F. (ed.) Fossilium Catalogus. Vol. 1, Animalia, Pars 42.140 pp. W. Junk, Berlin.

SCUDDER, S.H. 1882. Nomenclator zoologicus: An alphabetical list of all generic names that have been employed by natural- ists for recent and fossil animals from the earliest times to the close of the year 1879. Bulletin of the United States National Museum 19, 1-340. DOI 10.5962/bhl.title.1143

ShCHERBAKov, D.E. 2008. Madygen, Triassic Lagerstätte number one, before and after Sharov. Alavesia 2, 113-124.

Siebold, C.T.E. \& Stannius, H. 1848. Lehrbuch der vergleichenden Anatomie. Theil 2, Lehbuch der vergleichenden Antomie der Wirbellosen Thiere. XII + 484 pp. Veit \& Comp., Berlin.

Skovsted, C.B. \& PeEl, J.S. 2011. Hyolithellus in life position from the Lower Cambrian of North Greenland. Journal of Paleontology 85(1), 37-47. DOI 10.1666/10-065.1

Streng, M. \& EbBestad, J.O.R. 2007. New palaeoscolecids from the Cambrian of Scandinavia. Lundadagarna $i$ historisk geologi och paleontologi X. Abstracts with programme, 44.

Swinnerton, H.H. 1915. Suggestions for a revised classification of trilobites. Geological Magazine (new series) 6(2), 487-496, 538-545. DOI 10.1017/S0016756800203634

Topper, T.P., Brock, G.A., Skovsted, C.B. \& Paterson, J.R. 2010. Palaeoscolecid scleritome fragments with Hadimopanella plates from the early Cambrian of South Australia. Geological Magazine 147(1), 86-97. DOI 10.1017/S0016756809990082

TopPer, T.P., Harper, D.A.T. \& Brock, G.A. 2013. Ancestral billingsellides and the evolution and phylogenetic relationships of early rhynchonelliform brachiopods. Journal of Systematic Palaeontology 11(7), 821-833.

DOI 10.1080/14772019.2012.728253

Ulrich, E.O. \& CoOPER, G.A. 1938. Ozarkian and Canadian Brachiopoda. Geological Society of America Special Paper $13,1-323$.

VAN DEN BoOGAARD, M. 1983. The occurrence of Hadimopanella oezgueli Gedik in the Lancara Formation in NW Spain. Proceedings of the Koninklijke Nederlandse Akademie van Wetenschappen B 86, 331-341.

VAN DEN BoOgaARD, M. 1989. A problematic microfossil, Hadimopanella? coronata sp. nov., from the Ordovician of Estonia. Proceedings of the Koninklijke Nederlandse Akademie van Wetenschappen B 92, 179-190.

Voigt, S., Buchwitz, M., Fischer, J., Krause, D. \& Georgi, R. 2009. Feather-like development of Triassic diapsid skin appendages. Naturwissenschaften 96(1), 81-86. DOI 10.1007/s00114-008-0453-1

Voigt, S., Haubold, H., Meng, S., Krause, D., BuchantschenKo, J., Ruckwied, K. \& Götz, A.E. 2006. Die FossilLagerstätte Madygen: Ein Beitrag zur Geologie und Paläontologie der Madygen-Formation (Mittel- bis Ober-Trias, SW-Kirgisistan, Zentralasien). Hallesches Jahrbuch für Geowissenschaften B, Beiheft 22, 85-119.

Voigt, S. \& Hoppe, D. 2010. Mass occurrence of penetrative trace fossils in Triassic lake deposits (Madygen fossil site, Kyrgyzstan, Central Asia). Ichnos 17(1), 1-11. DOI 10.1080/10420940903358081

Walcott, C.D. 1886. Second contribution to the studies on the Cambrian fauna of North America. Bulletin of the United States Geological Survey 30, 1-369.

WalcotT, C.D. 1889. Description of new genera and species of 
fossils from the Middle Cambrian. Proceedings of the United States National Museum 11, 441-446.

DOI 10.5479/si.00963801.11-738.441

WaLCotT, C.D. 1905. Cambrian Brachiopoda with descriptions of new genera and species. Proceedings of the United States National Museum 28, 227-337.

DOI 10.5479/si.00963801.1395.227

Walcott, C.D. 1908. Cambrian geology and paleontology, No. 4 - Classification and terminology of the Cambrian Brachiopoda. Smithsonian Miscellaneous Collections 53, 139-165.

Wenz, W. 1938. Gastropoda, Teil 1. Allgemeiner Teil und Prosobranchia. In Schindewolf, O.H. (ed.) Handbuch der Paläozoologie 6. 1639 pp. Borntraeger, Berlin.

WhitTARd, W.F. 1953. Palaeoscolex piscatorum gen. et sp. nov., a worm from the Tremadocian of Shropshire. Quarterly Journal of the Geological Society of London 109, 125-136. DOI 10.1144/GSL.JGS.1953.109.01-04.07

Williams, A., Carlson, S.J., Brunton, C.H.C., Holmer, L.E. \& Popov, L. 1996. A supra-ordinal classification of the Brachiopoda. Philosophical Transactions of the Royal Society of London B 351, 1171-1193. DOI 10.1098/rstb.1996.0101
Williams, A. \& Harper, D.A.T. 2000a. Protorthida, 709-714. In Williams, A. et al. Treatise on Invertebrate Paleontology. Part H, Brachiopoda, Revised, vol. 3. Geological Society of America \& University of Kansas, Boulder \& Lawrence.

Williams, A. \& Harper, D.A.T. 2000b. Orthida, 714-844. In Williams, A. et al. Treatise on Invertebrate Paleontology. Part H, Brachiopoda, Revised, vol. 3. Geological Society of America \& University of Kansas, Boulder \& Lawrence.

Wrona, R. 1982. Early Cambrian phosphatic microfossils from southern Spitsbergen (Hornsund region). Palaeontologia Polonica 43, 9-16.

Wrona, R. \& Hamdi, B. 2001. Palaeoscolecid sclerites from the Upper Cambrian Mila Formation of the Shahmirzad section, Alborz Mountains, northern Iran. Acta Geologica Polonica 51(2), 101-107.

Yin, A. 2010. Cenozoic tectonic evolution of Asia: A preliminary synthesis. Tectonophysics 488(1-4), 293-325. DOI 10.1016/j.tecto.2009.06.002

Yuan, K.-X. \& Zhang, S.-G. 1983. Discovery of the Tommotia fauna in SW China. Acta Palaeontologica Sinica 22, 31-39. [in Chinese with English summary] 